\title{
Azerbaycan Cecimlerinin \\ Sanatsal ve Teknik Özellikleri ile
}

\section{Günümüzdeki Durumu}

\section{ÖZET}

Azerbaycan dokumacılık sanatında cecim önemli bir yere sahiptir. Al-elvan boyuna şeritli kompozisyonu ile dikkat çeken cecimler özellikle Şamakhı, Berde, Ağcabedi, Nakhçıvan, Cebrayıl, Zengilan, Lemberan ve Şuşa Bölgelerinde daha çok dokunmuştur.

Azerbaycan cecimi, genelde yün, saf ipek, bazen de yün ve pamuk veya ipek ve pamuk ipliklerle yapılan çözgü yüzlü düz dokumadır. Yaklaşık 15-33 $\mathrm{cm}$ genişlikte ve $15 \mathrm{~m}$ uzunluklu parçalar halinde dokunur. Cecimin kompozisyonu, düz renkli şeritlerin sıralanmasından oluştuğu gibi, düz ve desenli şeritlerin ya da sadece desenli şeritlerin sıralanmasından da oluşabilir. Kullanılan süslemelerin büyük kısmı geometrik olmakla birlikte, bitkisel süslemelere de rastlamak mümkündür. Azerbaycan'da dokunan cecimlerde kırk civarında farklı kompozisyon çeşidi tespit edilmiştir. Azerbaycan cecimlerinde kırmızı, yeşil, lacivert, kahve, sarı, siyah, beyaz gibi renkler daha fazla görülmektedir.

Cecim çoğunlukla yatay tezgâhlarda dokunur. Çözgü ipliklerinin dokumadaki sıklığı, atkı ipliklerinin sıklığından 4-5 kat fazladır. Desenli şeritlerde desen genelde iki renk çözgü ile oluşturulmaktadır. Bunlardan birisi yüzeye çıktığı zaman diğeri dokumanın alt tarafında kalıyor ve sırası geldiğinde çözgüler yer değiştiriyorlar.

Azerbaycan'da cecimin dokunma tarihinin yeterince eski olduğu düşünülmektedir. Daha XIV. yüzyıldan kalan Tebriz minyatürlerinde cecim örneklerinin tasvirlerine rastlanmaktadır.

Doç. Dr., Atatürk Üniversitesi, Güzel Sanatlar Fakültesi, Tekstil ve Moda Tasarımı Bölümü, Erzurum,

e-posta: pashayeva@hotmail.com
Cecim, Azerbaycan'ın zengin dokumacılık geleneklerini yansıtan, bu gelenekleri çok eski zamanlardan günümüze taşıyan; hem halkın, hem de soyluların yaygın şekilde kullandığı dokuma çeşidi olarak tekstil tarihimiz açısından büyük önem arz etmektedir. Ne yazık ki, günümüzde cecim dokumacıllı̆̆ yok denecek duruma gelmiştir.

Anahtar Kelimeler: Azerbaycan Dokumaları, Düz Dokuma Yaygı, Çözgü Yüzlü Dokuma, Cecim, Kompozisyon.

\section{ABSTRACT}

Jejims have a special place in Azerbaijan textile art. They were made in Shamakhi, Berde, Agjabedi, Nakhchivan, Cebrayil, Zengilan, Lemberan, Shusha etc.

Azerbaijan jejims are the warp-faced textiles. They are usually made of wool, wool and cotton or silk and cotton in some areas and pure silk. They are made as bands of normally $15-35 \mathrm{~cm}$ in width and up to $15 \mathrm{~m}$ in length. Their composition consists of plain or patterned narrow vertical stripes or plain and patterned stripes together. Motifs of jejim covers are frequently geometrical, but sometimes one can see flowers also. There are about 40 different composition variants of Azerbaijan jejims, in which red, yellow, green, blue, brown, black and white colours were used more.

Generally, Azerbaijan jejims were woven on horizontal looms. The warp density of jejims exceeds their weft density up to 4-5 times. In patterned stripes patterns are formed by two colours. When one colour interlaces $1 / 1$ on the front of the fabric, the other floats on the back of the next pattern area, where it substitutes the other. 
It is supposed that the history of the jejim production in Azerbaijan is quite old. There are depictions of jejim like textiles in some Tabriz miniatures dated to 14 th century.

Jejims have a great importance for the textile art history of Azerbaijan. They reflect the rich weaving traditions of Azerbaijan people, which, unfortunately, come to an end nowadays.

Keywords: Azerbaijan textiles, Flat-woven rug, Warp-faced textile, Jejim, Composition.

\section{Giriş}

Eski köklere sahip Azerbaycan dokumacılık sanatında cecimin kendine özgü yeri vardır. Cecim, düz dokuma yaygı ve kumaş olarak bilinen tüm diğer dokuma çeşitlerinden farklı olarak her iki tipe de ait edilmektedir. Azerbaycan'da havsız halılar olarak adlandırılan düz dokuma yaygıların bir çeşidi gibi yün veya pamuktan veya ikisinin karışımından üretilmiş cecimler çadır döşeneceği, battaniye, duvar askısı, kürsü örtüsü, taht örtüsü vs. kısmında kullanılmıştır. Diğer taraftan, ipekten üretilmiş cecimler kumaş olarak bayan ve erkek giysilerinin, yorgan, döşek, minder, mütekke ve yastık yüzü, perde, çeşitli örtüler (masa, yatak, at vs.), çanta, bohça, heybe vs. hazırlanmasında kullanılmıştır. Bu nedenle de cecimler hem düz yaygılara, hem de kumaşlar sınıfına dâhil edilmektedir.

L. Kerimov (1983: 203), “cecim” isminin Azerbaycan'ın Berde ve Laçın Bölgelerinde yerleşen "Cecimli" köylerinin ismi ile bağlı olabileceğini öne sürüyor. Fakat Azerbaycan ve Orta Doğu klasik edebiyatında "cacim" isminin kullanıldı̆̆ını kaydediyor. Günümüzde Farsçada "cacim”, Azerbaycan Türkçesinde (hem Kuzey'de, hem de Güney'de) “cecim”, Anadolu Türkçesinde "cecim” / "cicim” ismi (Görgünay 2001: 11) kullanılmaktadır. Azerbaycan'da dokuma tekniğine, sanatsal özelliklerine, malzemesine, kullanım alanına vs. bağlı olarak cecimler farklı isimlerle adlandırılmışlardı: alaköynek, hemyan, ip cecimi, obagezer, çiçekli, saya cecim, oyankeçi, ladı-cecim, şedde-cecim, yer cecimi, darayı cecim, hayati cecim, gara cecim, kalıplı cecim, elbiselik cecim, çoban cecimi vs. (Aliyeva 1988: 50, Aliyeva 1990: 34-35, Tağıyeva 2006: 71).

Cecim - çeşitli renklerde boyuna şeritlerden oluşan kompozisyona sahip, ensiz ve uzun parçalar halinde üretilen çözgü yüzlü dokuma çeşididir. Yatay yer tezgâhında dokunan cecimin eni $25-30 \mathrm{~cm}$, uzunluğu ise $15 \mathrm{~m}$ civarındadır. Hazırlanacak ürünün ebadına bağlı olarak bu şeritten gereken uzunlukta parçalar kesilerek yanlarından birbirine dikilmekle gereken genişlik ve uzunluğa sahip ürün elde edilir. Cecimin göçebe toplumlara ait bir dokuma çeşidi olduğu düşünülmektedir. Onun genelde açık havada kurulmuş basit yer tezgâhında dokunması da bu düşünceye

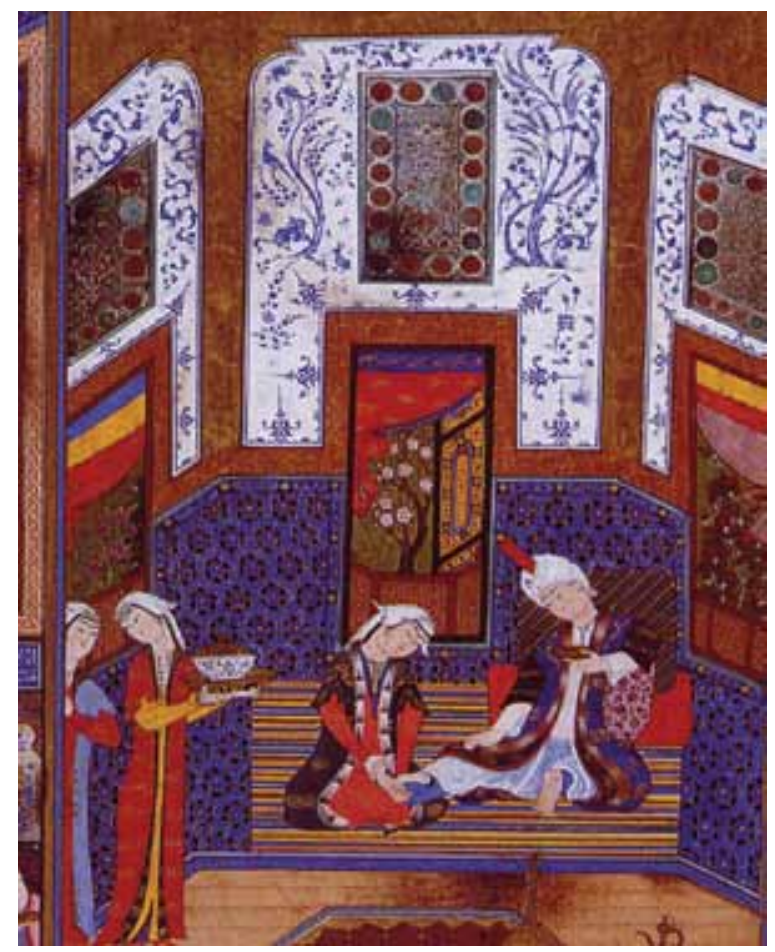

Foto 1. Nizami, "Hamse". "Behram Gur

destek vermektedir. Orta Asya'dan Anadolu'ya kadar geniş bir mekânda bu dokuma çeşidi üretilmiştir. Cecim göçebe toplumların günlük yaşamında çok yaygın olarak kullanılan dokuma çeşitlerinden biri olmuştur.

Günümüze ulaşmış eski cecim örnekleri çoğunlukla XIX. yüzyıla ait olsa da, bu dokumanın çok daha erken devirlerde ortaya çıktığı düşünülmektedir. XIVXVI. yüzyıl Tebriz ve Herat minyatürlerinde cecime benzer ürüne örtü, çanta, gölgelik kenarı, yorgandöşek veya minder yüzü olarak rastlanmaktadır ${ }^{1}$ (Foto 1.). Bu minyatürlerde görülen ve cecime benzeyen ürünlerin kesinlikle cecim olduğu veya hangi malzemeden hazırlanmış olduğu konusunda, doğal olarak net bir fikir söylenemez. Fakat zahiri görünüşüne, kompozisyon özelliklerine göre cecimi çağrıştırdığı kesindir. Hatta bazı minyatürlerde örtünün başka renkli materyalle kaplanmış arka yüzü de görülmektedir² ki, arkasında uzun iplik örtüleri veya uçlarının bulunduğu bir ürünün arka tarafının böyle kaplanması doğaldır.

\footnotetext{
Bkz., "Kelile ve Dimne" eserinin elyazmasından "Akıllı Tacir ve Saf Hırsız" minyatürü, 1360-1374 (İstanbul Üniversitesi Kütüphanesi, F.1422); Şah Tahmasib "Şahname"sinden "Rüstem'in Rakhş'1 Afrasiyab'ın sürüsünden geri alması" (özel koleksiyon, Lihtenştayn), "Key Hüsrev'ın Afrasiyab'ı Öldürmesi" (Çağdaş Sanat Müzesi, Tahran) minyatürleri, 1530-35; Nizami'nin "Hamse"sinin 1480-1505 tarihli elyazmasından "Behram Gur ve Prenses Yeşil Sarayda" (Topkapı Sarayı Müzesi, İstanbul, inv. No. H762), "Behram Gur ve Prenses Beyaz Sarayda" (Topkap1 Sarayı Müzesi, İstanbul, inv. No. K412) minyatürleri; Firdevsi'nin "Şahname" eserinin 1429 tarihli elyazmasından "Hüsrev'in yok olması" minyatürü (Gülüstan Sarayı Kütüphanesi, Tahran) vs.

2 Örneğin, "Kelile ve Dimne" eserinin el yazmasından "Akıllı Tacir ve Saf Hırsız" minyatüründe olduğu gibi.
} 


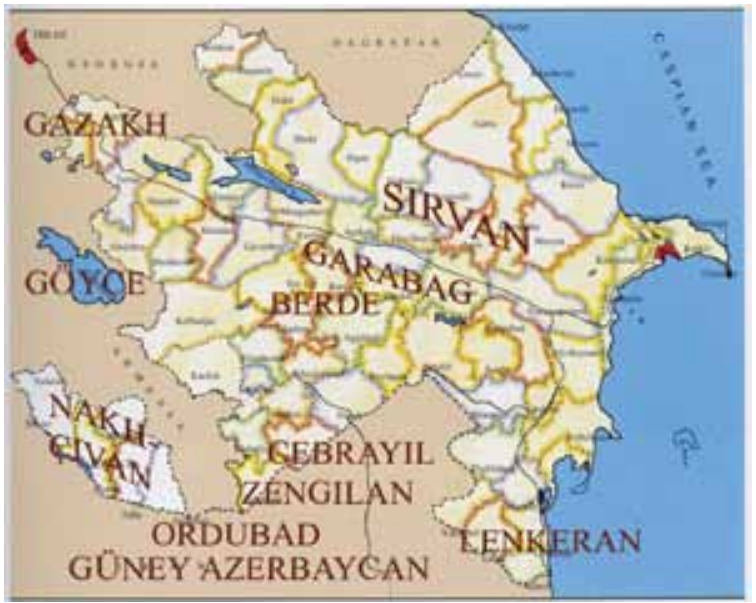

Harita 1. Azerbaycan'ın Cecim Dokumacılık Bölgeleri

Çadırlarda yere döşenen cecimlerin arka kısmının genelde keçe ile kaplandığı bilinmektedir.

Azerbaycan'da cecimin esas üretim merkezleri Şirvan, Garabağ (özellikle Lemberan), Berde, Gazakh, Nakhçıvan, Ordubad, Cebrayıl, Zengilan, Lenkeran, Göyçe ve Güney Azerbaycan olmuştur (Harita 1.). Bazı kaynaklarda Azerbaycan'ın ayrı-ayrı bölgelerinde ve hatta köylerinde cecim dokumacılı̆̆ı ile ilgili notlara rastlanmaktadır (Bagirzade 1926: 105, Abdullayeva 1971: 34, Piralov 1913a: 58). Genel olarak Azerbaycan'ın güney bölgelerinde çeşitli düz dokuma yaygıların ve o sıradan da cecimlerin daha fazla dokunduğu kaydediliyor.

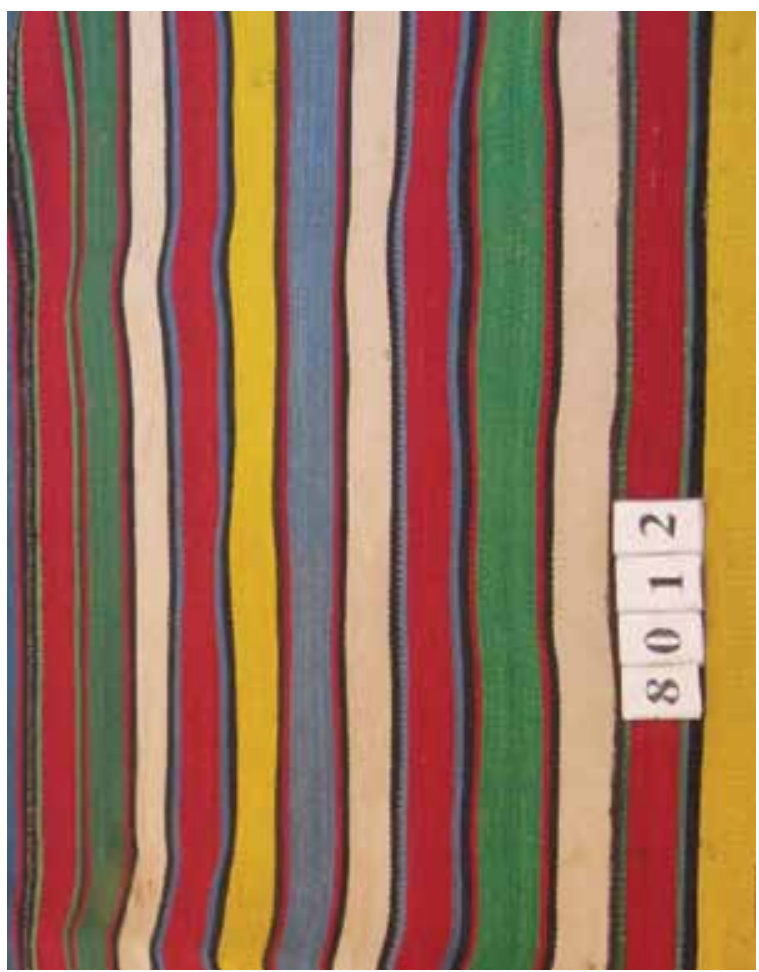

Foto 2. Düz Şeritli İpekli Cecim Örneği. 85 x ve Prenses Beyaz Sarayda". 1480 - 1505. 132 cm. Cebrayıl. Azerbaycan Tarihi Topkapı Sarayı Müzesi, İstanbul, inv. no. Müzesi, Bakü, inv. no. 8012. K412.

\section{Azerbaycan Cecimlerinin Kompozisyon Özellikleri}

Azerbaycan cecimlerinin kompozisyonu değişik renklerde ve genişlikte düz veya desenli şeritlerin veya her ikisinin ritmik şekilde tekrarlanmasından oluşmaktadır. Cecim desenleri o kadar büyük çeşitliliğe sahiptir ki, bunların hepsini kapsayarak ayrı ayrı ele almak çok zordur. Fakat genel çizgileri ile başlıca özelliklerden söz edebiliriz. Yaklaşık 40 farklı desen çeşidinin olduğu araştırmacılar tarafından kaydedilmektedir (Wright 1992: 79).

Kompozisyon tipine göre cecimleri iki büyük gruba ayırabiliriz: 1. Kompozisyonu düz renkli şeritlerden oluşan cecimler; 2. Kompozisyonu desenli şeritlerden oluşan cecimler. Ama şunu kaydetmeliyiz ki, kompozisyonu sadece desenli şeritlerden oluşan cecimlere çok az rastlanmaktadır. Bu grupta genelde desenli şeritlerle düz şeritler ve onları ayıran ince suların (çizgilerin) sıralanmasından oluşan kompozisyonlardan söz edilebilir.

Birinci gruba ait cecimleri ele aldığımızda bunların kendi aralarında çeşitlilik arz ettiğini görebiliriz. Bu gruba dâhil edebileceğimiz cecimlerin büyük çoğunluğunda çok da geniş olmayan (bazen geniş de olabilen) değişik renklerde şeritler sıralanmıştır (Foto 2.). Şeritler kırmızı, sarı, yeşil, mavi, beyaz, turuncu, lacivert, bordo, pembe, yavruağzı, bej, siyah, kahve, gri vs. gibi en değişik renklerde olup her ürünün kendine özgü farklı şekilde seçilerek kullanılmıştır. Bu şeritlerin arasında ise açık ve koyu renklerde suların değişik

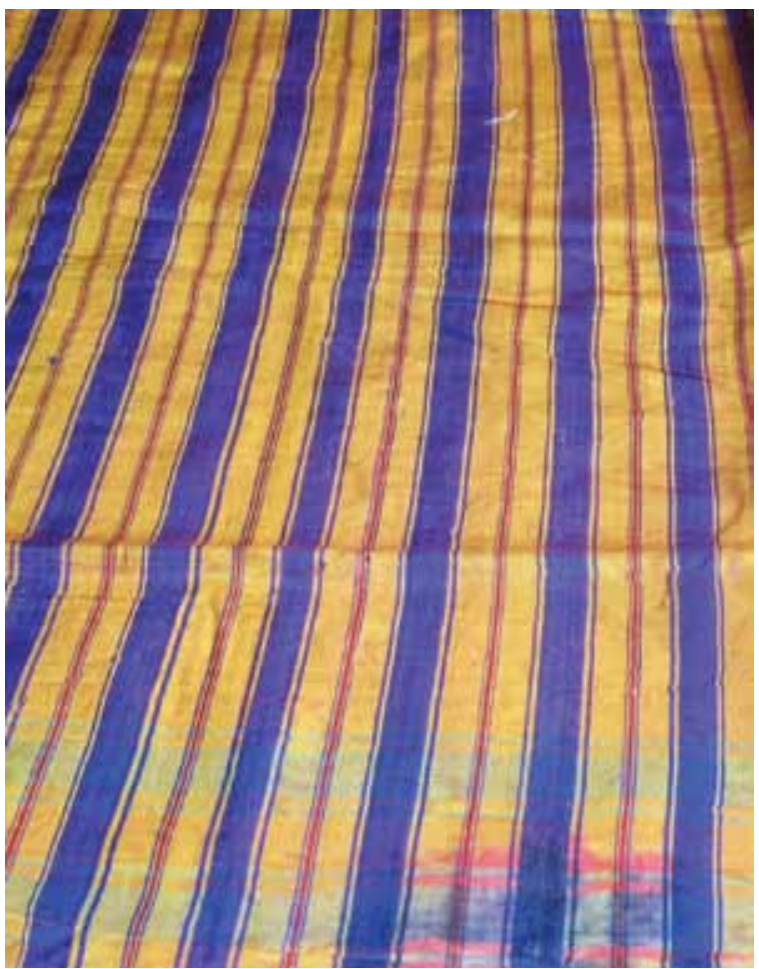

Foto 3. Kompozisyonu İki Renk Şeritten Oluşan İpekli Cecim Örneği. 83 x 93 cm. görüldüğü ipekli cecim örneği Azerbaycan Tarihi Müzesi, Bakü, inv. Nakhçıvan. Azerbaycan Tarihi Müzesi, no. 6110. 


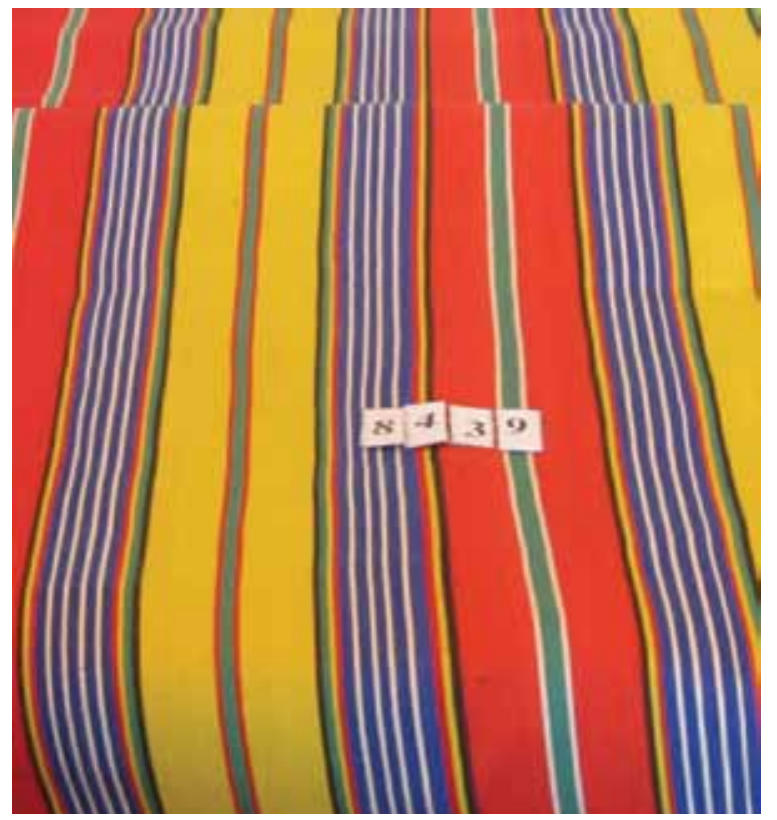

Foto 4. İki Renk Sudan Oluşan Su Grubunun Görüldüğü İpekli Cecim Örneği. 0,7 x12, 0 m. Nakhçıvan. Azerbaycan Tarihi Müzesi, Bakü, inv. no. 8439 .

düzenli birleşimi şeklinde su grupları yer almaktadır. Suların sayısı genelde iki ve daha fazla olmaktadır. Renkleri ise cecimin kompozisyonunu oluşturan şeritlerin renkleri ile aynı veya farklı renklerde de olabilir. Genelde sular kendine özgü bir düzenle gruplaştırılmaktadır. Örneğin, en dıştaki sular hemen yanlarında yerleşen şeridin rengine zıt koyu renkte, onlardan içte yerleşen sular daha koyu ve ortada yerleşen su ise açık renkte olabilir. Böyle bir su grubundan sonra gelen şeridin rengi daha belirgin bir şekilde ortaya çıkarak daha etkileyici olmaktadır. Sadece şeritler ve sularla çok çarpıcı kompozisyonlar oluşturan dokumacıların ustalığı, onların renkleri, şeritlerin ve suların genişliğini çok iyi kullanmalarına bağlıdır. Bazen cecimin renkleri gök kuşağı kadar etkileyici olduğu içindir ki, halk arasında gök kuşağı ile ilgili "Karı nene cecimini serdi" deyimi kullanılmıştır. Bazı örneklerde ise suların renkleri şeritlerin veya onlardan birinin rengine çok yakın olup hepsi birlikte bir şerit gibi algılanmakta ve cecimin genel kompozisyonunun daha sakin görünümünü sağlamaktadır.

Birinci gruba ait edebileceğimiz cecimlerin bir kısmında şeritler iki alternatif renkte, onların arasında yer alan sular ise şeritlerin renkleri de dâhil çeşitli açık ve koyu renklerde yapılarak cecimin kompozisyonuna daha dinamik karakter verilmiştir (Foto 3.). Bu ürünlerde en yaygın renkler kırmızı, lacivert, sarı, yeşil ve beyazdır. Bu tip cecimlerde şeritler biraz daha geniş olup iki ve daha fazla su kullanılmış olabilir. Bazı cecimlerde geniş şeritlerin ortasında da sular yerleştirilerek şerit daha ensiz kısımlara ayrılır ve kompozisyon daha zengin görünüme kavuşturulur (Foto 3.). Bazı örneklerde ise sadece iki renkte sular sıralanarak en dişta farklı renkte sulara yer verilir (Foto 4.). Foto 4.'te görüldüğü gibi, bir cecimdeki su grupları farklı şekillerde de olabilir.

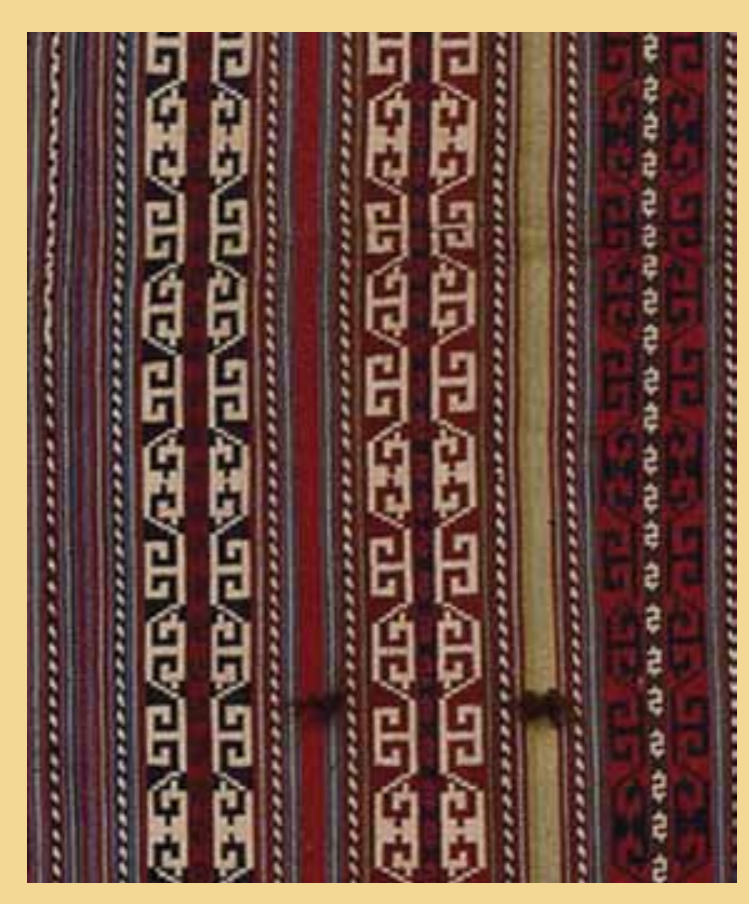

Yünlü Cecim. $197 \times 171 \mathrm{~cm}$ Özel koleksiyon

Paris. (Gans-Ruedin 1986: 352)

Foto 5. Desenli geniş şeritler grubu ile düz şeridin sıralandı̆̆ı cecim örnekleri.

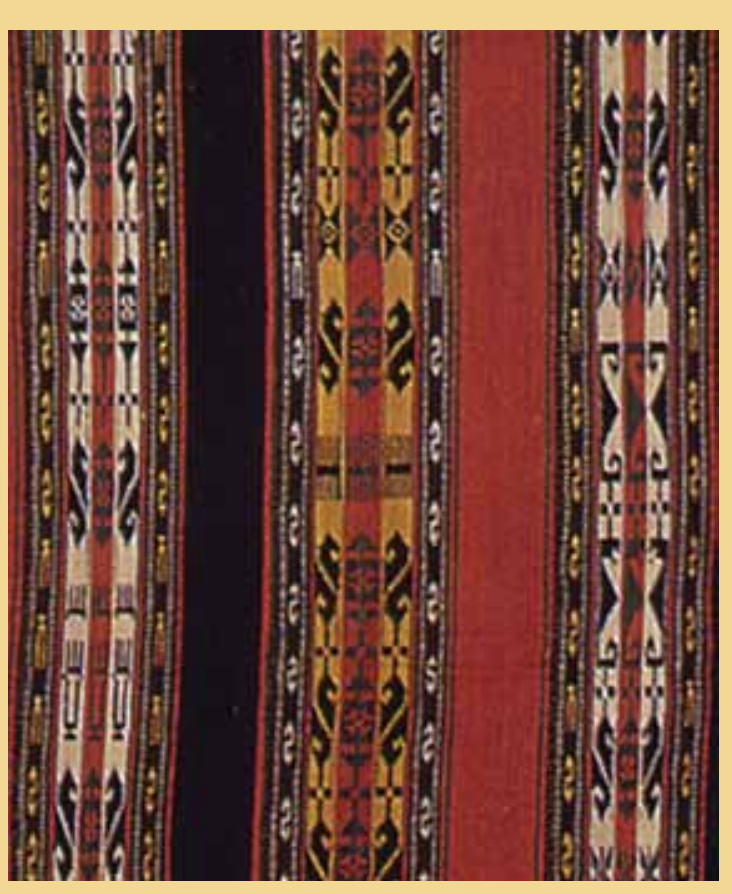

Yünlü Cecim, 165 x $241 \mathrm{~cm}$. Garabă̆. R. H.

Nooter koleksiyonu, Washington. (Nooter vd. 2004: pl. 125) 

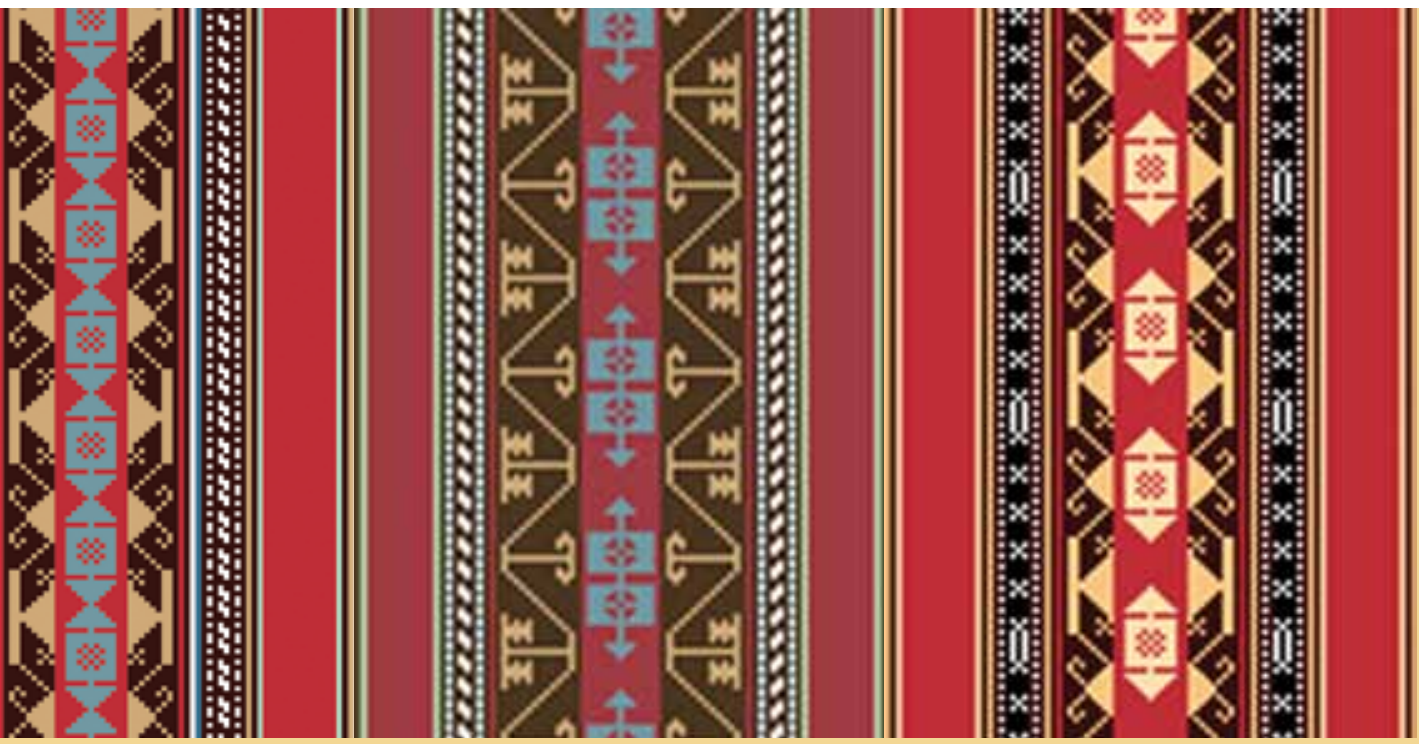

Şekil 1. Desenli Geniş Şeritler Grubunun Görüldüğü Cecim Kompozisyonları.

Kompozisyonu desenli şeritlerden oluşan cecimler de kendi aralarında farklılık göstermektedir. Bunların bir kısmında desenli şeritler belli bir düzenle birbirinin yanında yer alarak bir grup oluşturur ve bu grubun her iki tarafında kenarlarında sular olan düz renkli tek şerit yerleşmektedir (Foto 5a,b.). Böylece desenli ve düz şeritler sıralanarak kompozisyonu tamamlamaktadır. Bu tip cecimlerin bir kısmında desenli şeritler grubu genelde şöyle bir yapıya sahiptir: grubun merkezinde yönsüz motiflerin tekrarından oluşan desenle süslenmiş şerit, onun iki yanında ise ona doğru yönelmiş sürekli devam eden raportlu desenle süslü şeritler yer almaktadır (Şekil la, b, c). Bunlardan sonra sular ve Azerbaycan halıcılığında siçandişi (Kerimov
1961: 19) ismi ile bilinen küçük desenli suların arasında yerleşen daha ince bir şerit görülmektedir. Küçücük tek motiflerin tekrarlanması ile oluşturulmuş desenle süslü bu şeritten sonra iki taraftan sularla ayrılmış düz renkli tek şerit yer almakta ve anlattığımız desen yeniden tekrarlanmaktadır. Bu cecimlerde desenli şeritlerin zemininde kırmızı, kahverengi, lacivert, mavi, düz renkli şeritlerde ise genelde kırmızı, yeşil, bazen siyah renk kullanılmıştır. Motiflerde beyaz, sarı, mavi, açık yeşil, krem gibi açık renklere üstünlük verilmiş ve koyu zemin üzerinde onların belirgin görünmesi sağlanmıştır. Bazen koyu renkli motiflere de rastlanmaktadır. Şeritleri bir-birinden ayıran sularda hem koyu, hem de açık renkler, bazen de parlak renk-

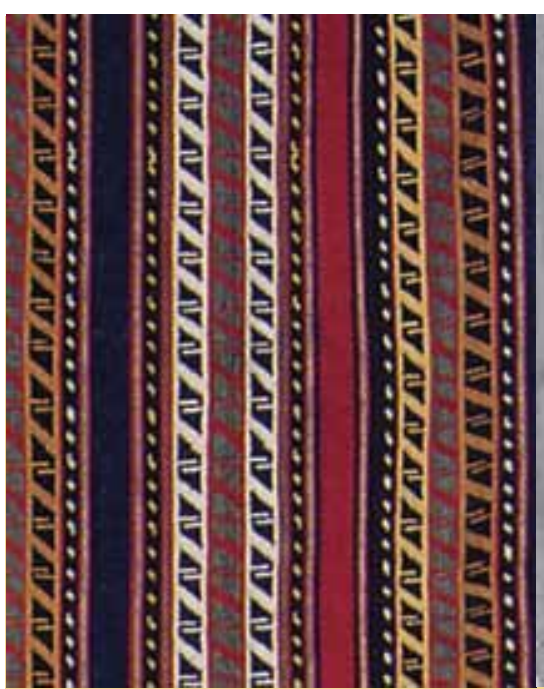

Yünlü Cecim. Azerbaycan Halçası

ve Halk Tatbiki Sanatı Devlet Müzesi, Bakü

Foto 6. Desenli ensiz şeritler grubu ile düz şeridin sıralandığı cecim örnekleri.

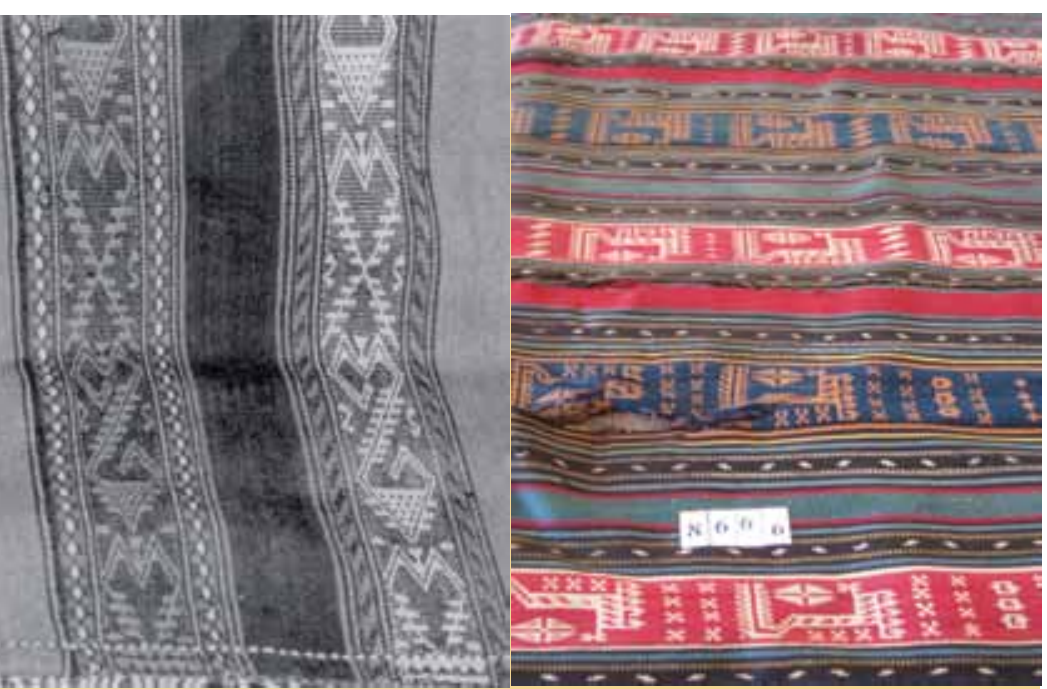

İpekli Cecim. 118 x $181 \mathrm{~cm}$. Qarabağ.

Azerbaycan Tarihi Müzesi, Bakü, inv. no. 8666. 

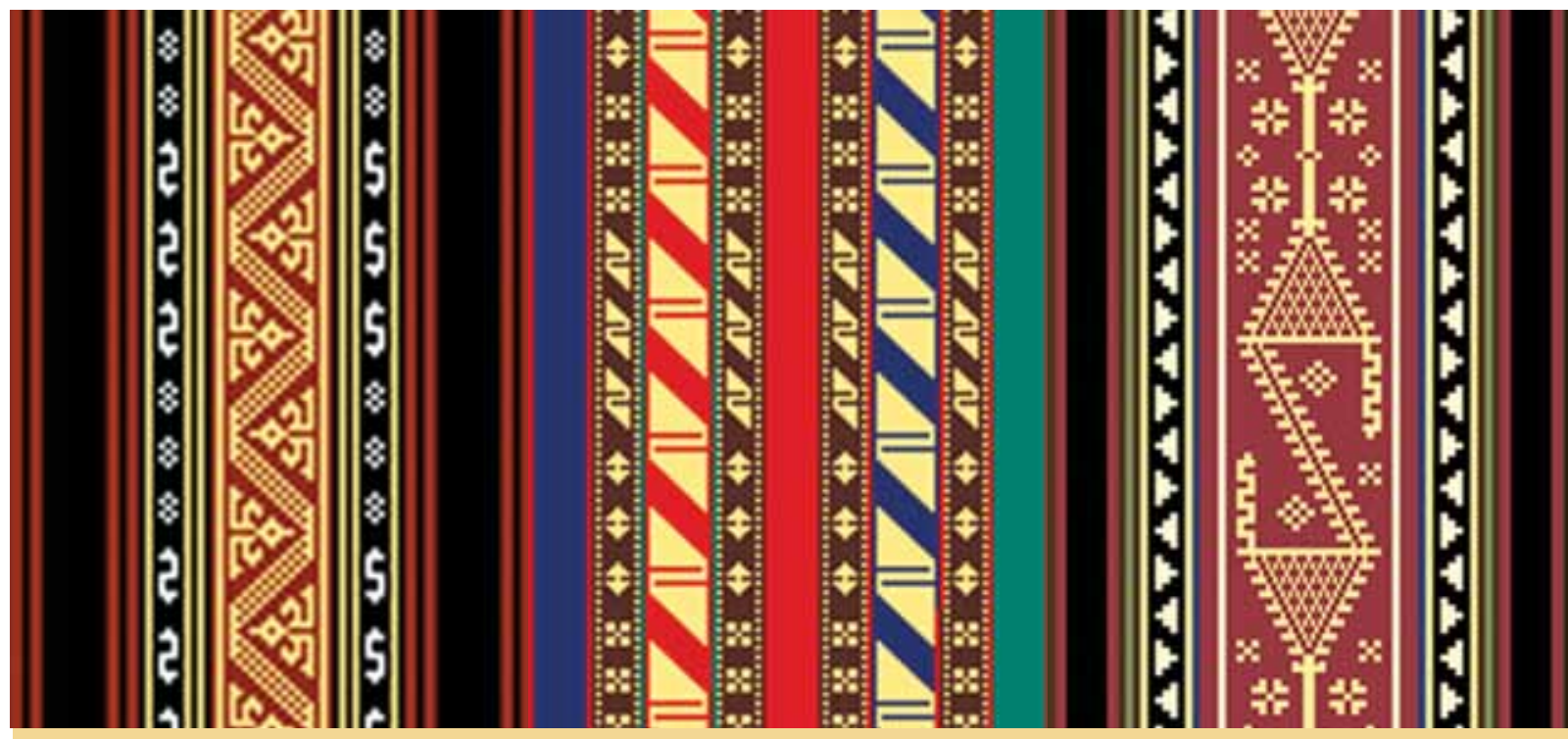

Şekil 2. Desenli Ensiz Şeritler Grubu Ile Düz Şeridin Sıralandığı Cecim Kompozisyonları

ler kullanılarak desene daha çekici görünüm verilmiş ve daha da zenginleştirilmiştir

Cecimlerin bir kısmında desenli şeritler grubunun yapısı yukarıda anlattığımızdan farklı olup daha ensiz ve daha az sayıda şeritten oluşmaktadır (Foto 6., Şekil 2.). Bu örneklerdeki desenli şeritler grubunun merkezinde çeşitli motiflerin tekrarlanmasından oluşan desenle süslü esas şerit ve onun kenarlarında ise siçandişi şeritler arasında yerleşmiş küçücük motiflerle süslü ince şerit görülmektedir. Bazen bu şeridin kendisi de siçandişi motifleri, özellikle de burma olarak adlandırılan motifle süslenir (Foto 6a)

Desenli cecimlerin bir kısmında desenli şeridin yanlarında sadece sular ve siçandişi görülmekte, de-

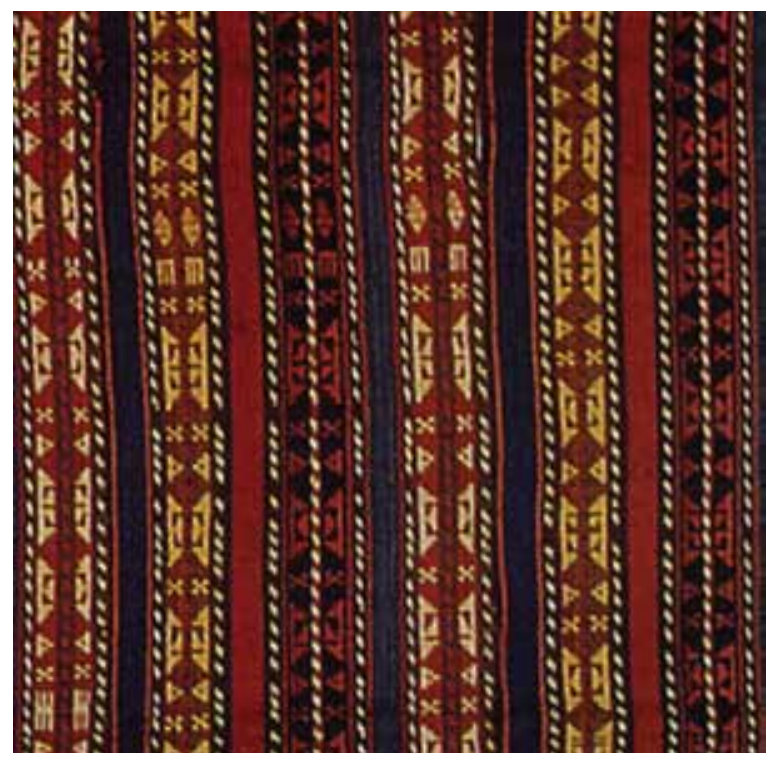

Foto 7. Desenli Tek Şeritle Düz Şeridin Sıralandı̆̆ı Yünlü Cecim Örneği. 157 x 200 cm. Şirvan R. H. Nooter koleksiyonu, Washington. (Nooter vd. 2004: pl. 126) senli şeritle düz renkli şerit sıra ile yerleşmektedirler (Foto 7., Şekil 3.). Bazen düz renkli şerit tek değil, birkaç şeritten oluşan grup halindedir.

Çok az sayıda desenli cecim örneği de vardır ki, bunlarda kompozisyonu oluşturan tüm şeritler desenlidir (Foto 8, Şekil 4.). Bazı Örneklerde şeritler arasında sular, bazılarında ise siçandişiler yer almaktadır. Bu cecimlerin bazılarında şeritleri süsleyen motifler birbirlerinden bir hayli aralı yerleşmişler (Foto 9.).

Desenli cecimlerin bir grubunda tek desenli klsım, düz renkli şeritlerin arasında yerleşen su gruplarının merkezinde yer alan siçandişi şeritlerdir (Foto 10). Aslında bunları desensiz cecimler grubuna dâhil etmek daha doğru olabilir. Bu cecimlerin renk düzeni, birinci grupta söz ettiğimiz cecimlerle aynıdır.

Desenli cecimlerde kullanılan motifler çoğunlukla düz dokuma yaygılarda ve halılarda kullanılan geometrik motifler ve onların benzerleridir (Şekil 5.). Lakin onların arasında küçük çiçek, çarkı-felek motiflerine, hatta zoomorfik motiflere bile rastlanmaktadır (Şekil 6.). Desenli cecimlerin kompozisyonu sanatsal ve estetik açıdan hem daha mükemmel, daha güzel olmakla beraber, hem de daha karmaşıktır. Teknik açıdan da onun dokunabilmesi, dokuyucunun daha yetenekli bir usta olmasını gerektiriyor.

\section{Azerbaycan Cecimlerinin Teknik Özellikleri}

Azerbaycan cecim dokumacılığında malzeme olarak yün, pamuk veya ipek kullanılır. Yünlü cecim, güzem olarak adlandırılan bahar kırkımı kuzu yününden üretilen ve cecime yumuşaklıkla parlaklık veren ince halı ipliğinden dokunur. Pamuklu cecimler çok yaygın değildir ve pamuk iplikler çoğu zaman yün ve ipekle beraber tatbik edilirler. Yüksek kaliteli ince ve zarif cecim dokumak için hem zarif telli ham ipek, hem de pişirilmiş, nispeten kalın 

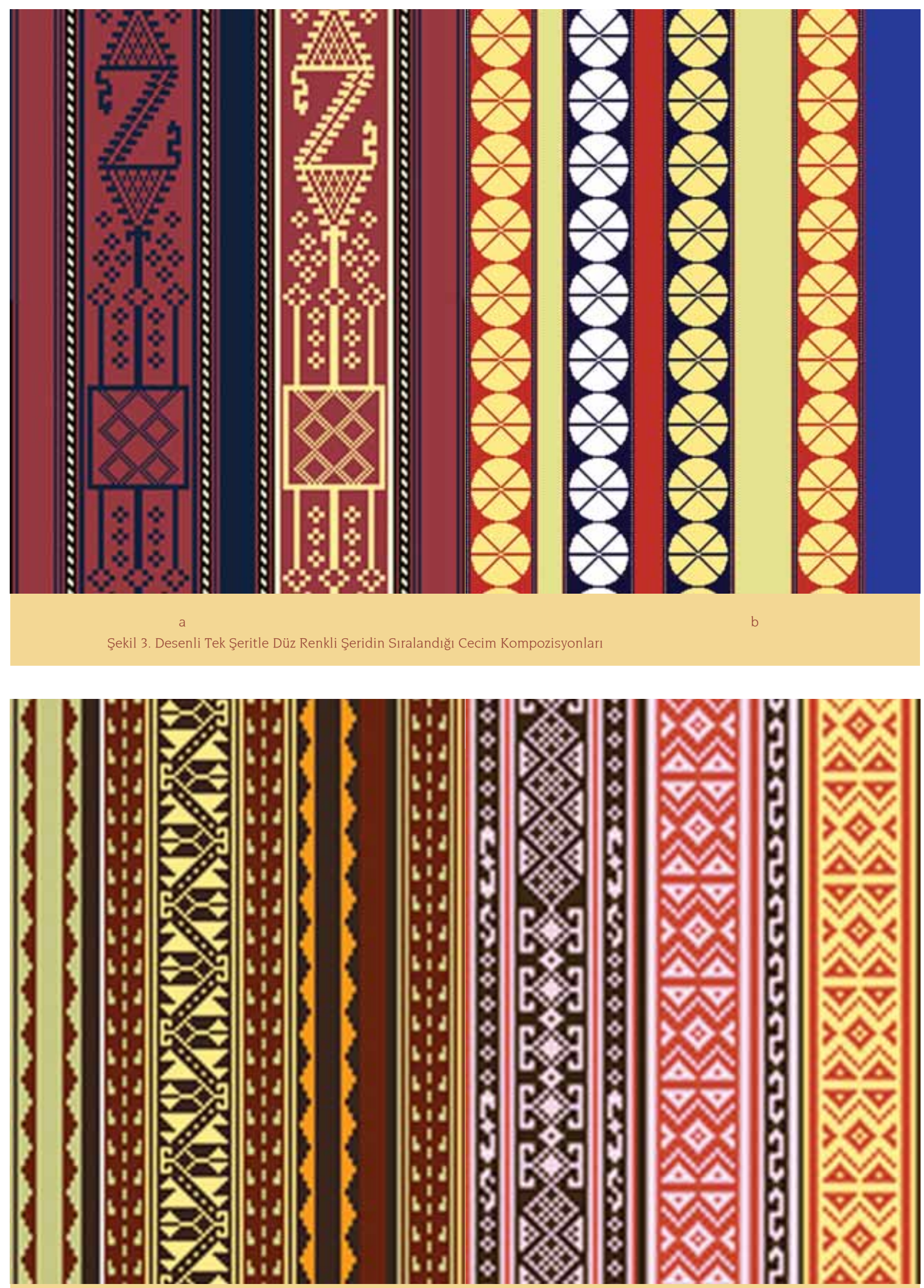


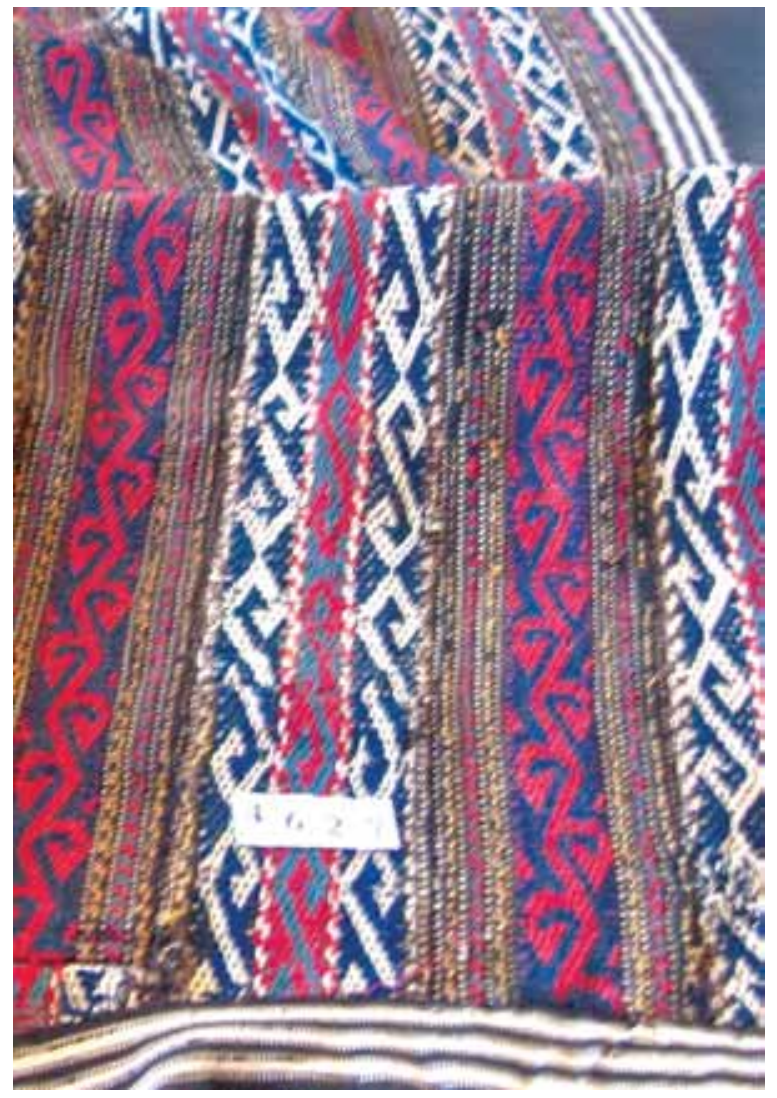

Foto 8. Tüm Şeritleri Desenli Yünlü Cecim Örneği. 108 x 160 cm 19. yy. Şamakhı. Azerbaycan Tarihi Müzesi, Bakü, inv. no. 4627

ve sağlam keci ipliği (aşağı kaliteli ipek kozasından elde edilen kalın ipek iplik) kullanılırdı (Vezirov 1929: 10). XX. yüzyılın başlarında Rusya Ekincilik Bakanlığının memuru olan A. S. Piralov, Kafkas'ta ipekçiliğin durumu hakkında yazarken yerli dokumacıların kullandığı ipeğin de özelliklerinden bahsetmiştir. Onun yazdığına göre (1913b: 79-80), fabrikada hazırlanan ipek iplikler sadece 5-10 ipek kozasından açılan tellerin birlikte bükülmesinden elde edildiği halde, el dokumacılığı için iptidai yöntemle 2.-3. kalite kozalardan hazırlanan iplik 20-40 adet kozadan elde edilirdi. Bu iplikler, doğal olarak, daha kalındı. Daha kaliteli ipek kozaları ise büyük miktarlarda ihraç edilirdi.

Üç adet ipekli Azerbaycan cecimini malzeme açısından tahlil etmiş J. L. Merritt (1992: 81), bu cecimlerde kullanılan ipeğin kaliteli Bombix mori ${ }^{3}$ cinsi olduğu ve hepsinin eğirilmiş ve bükülmüş iplikler olduğu kanaatine varmıştır. Yazar bu ipliklerin, ipek kozalarının rahat açılarak sarınan kısmından (çıkrık ipeği adlandırdığımız) değil, açılamayan kısmından hazırlandığını, fakat bunun hiç de liflerin taranması ve eğirilmesi sonucu elde edilen ipliklerin aşa$\breve{g ̆}$ kalitede olması anlamına gelmediğini özellikle

Böcekler sınıfının pulkanatlılar takımından ipekböceği kelebeğinin tırtılı.

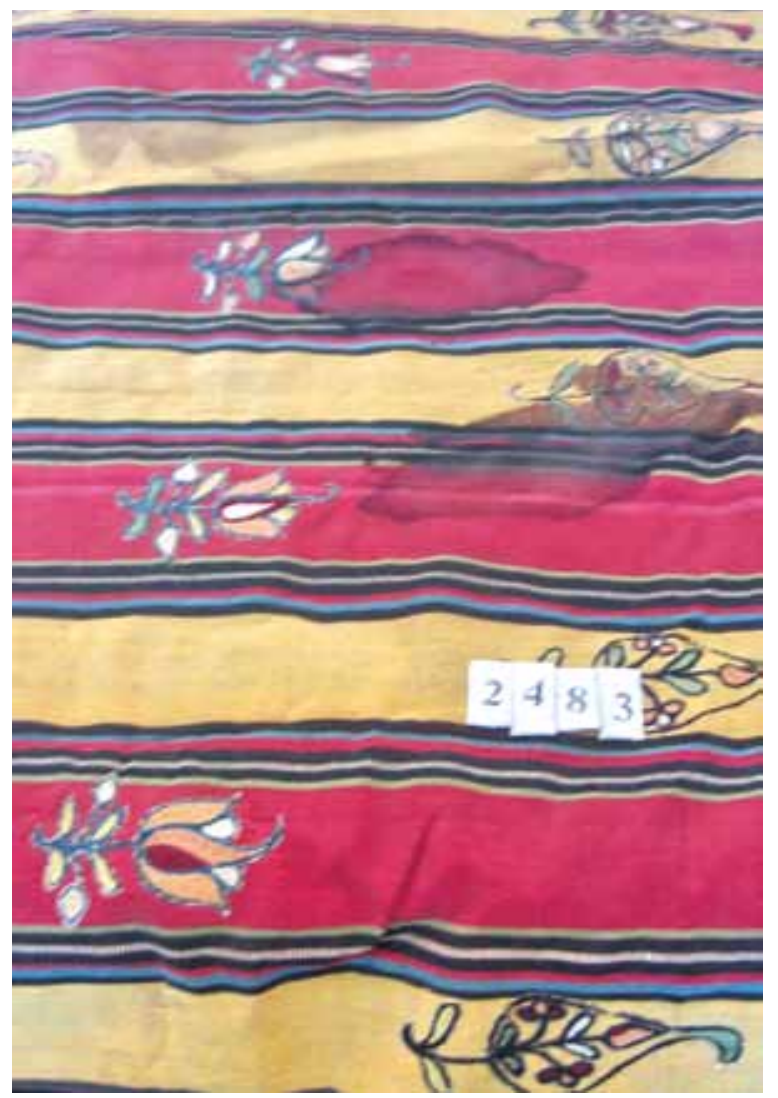

Foto 9. Tüm Şeritleri Desenli İpekli Cecim Örneği. 194 x 203 cm Azerbaycan Tarihi Müzesi, Bakü, inv. no. 2483

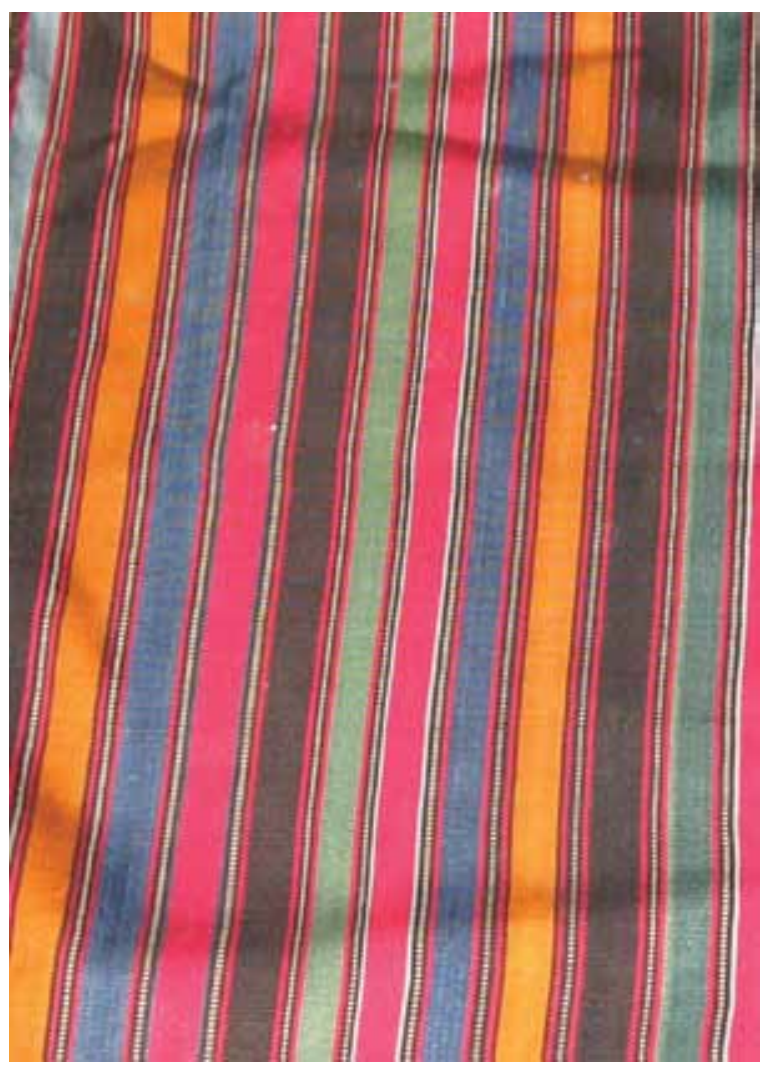

Foto 10. Düz Renkli Şeritler Arasında Siçandişi Şeritler Görülen İpekli Cecim Örneği. 135 x 230 cm. Azerbaycan Tarihi Müzesi, Bakü, inv. no. 6134. 


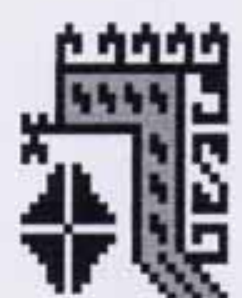 $3^{2}+23+2$ 5353525} a

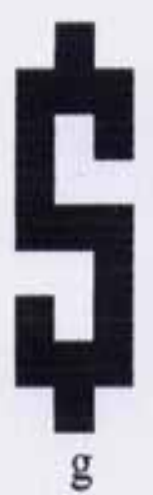

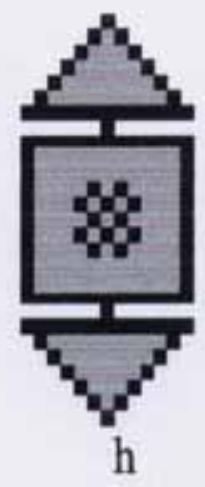

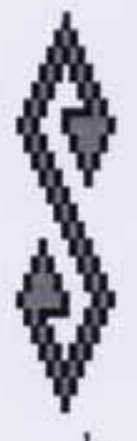

b

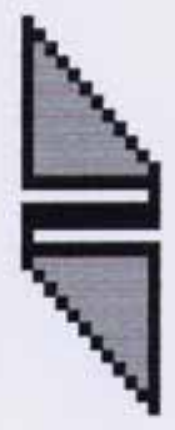

c

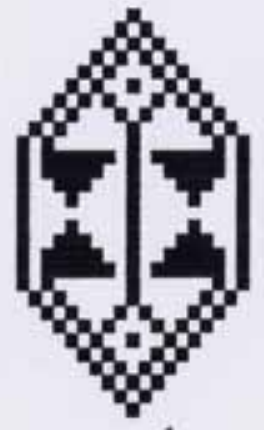

d

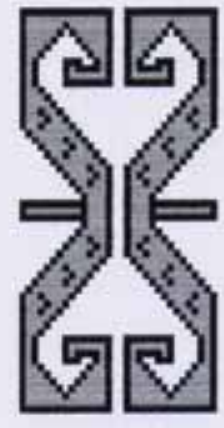

e

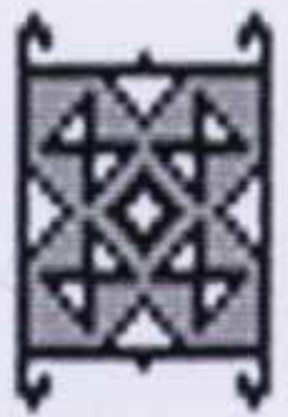

f
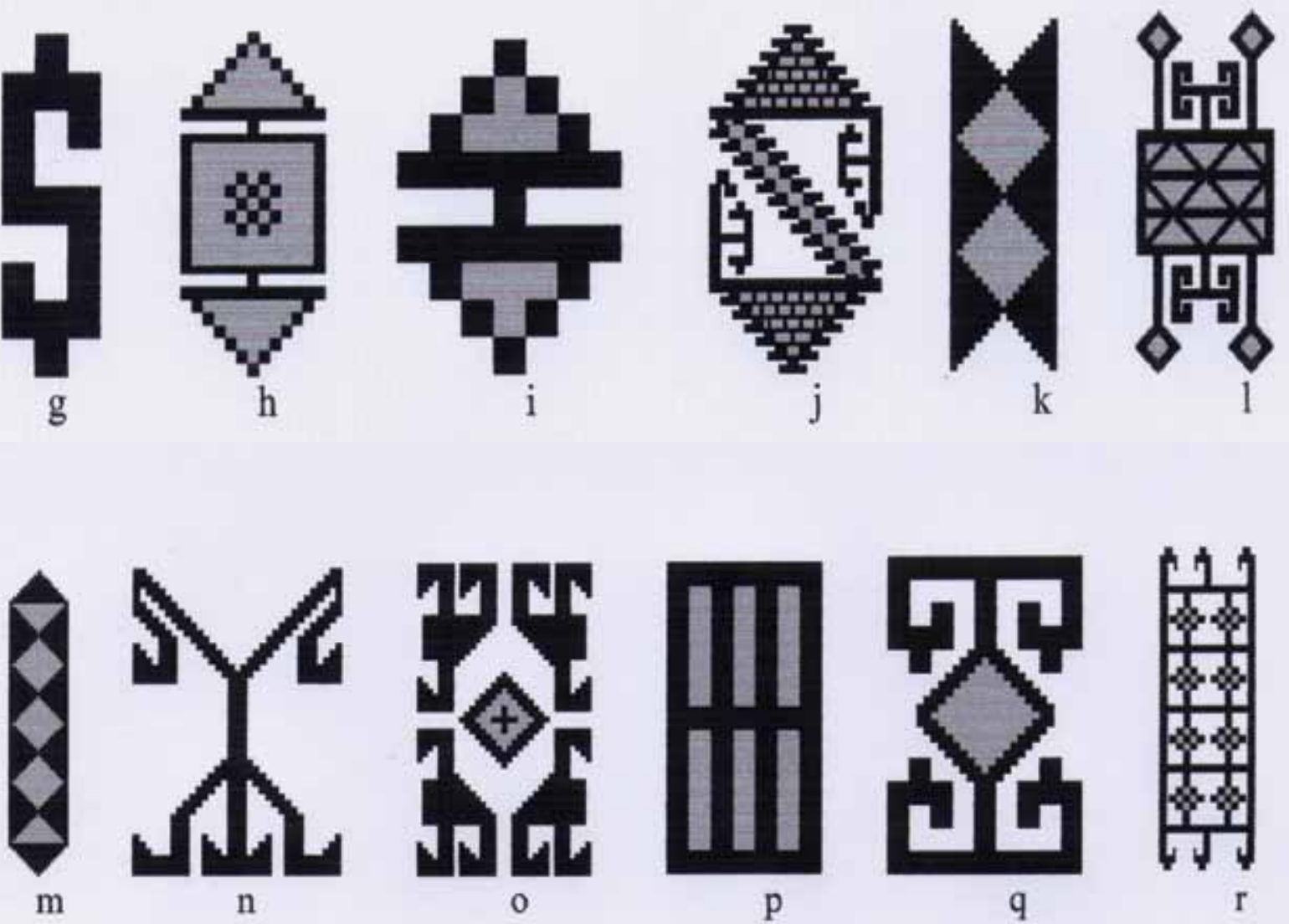

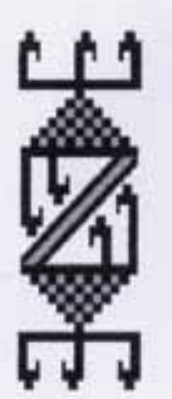

$\mathrm{s}$

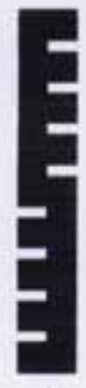

$\mathrm{t}$

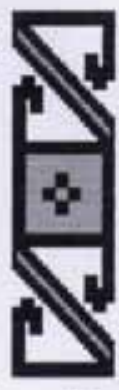

u

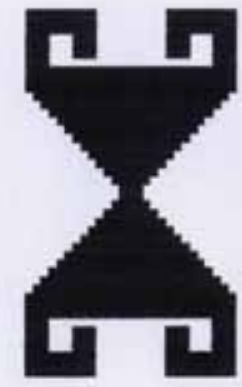

v

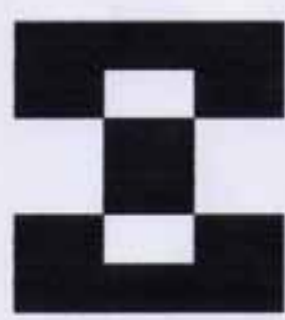

W

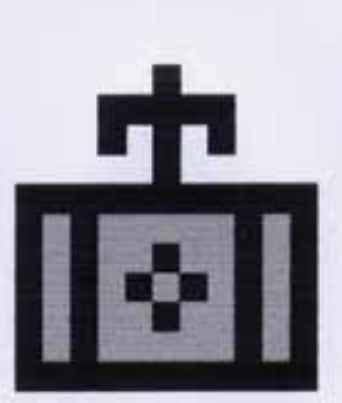

$\mathrm{X}$

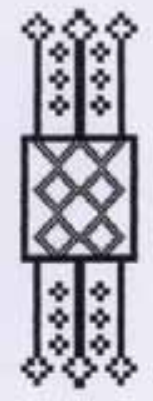

y 


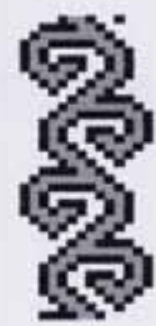

a

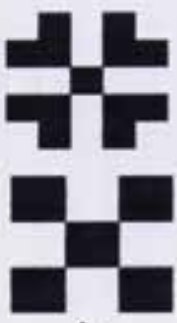

b

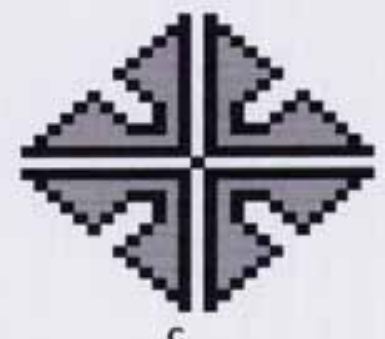

c

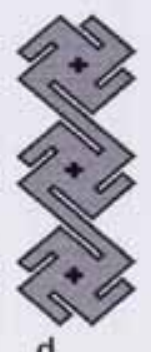

d

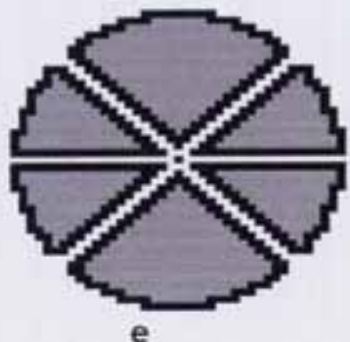

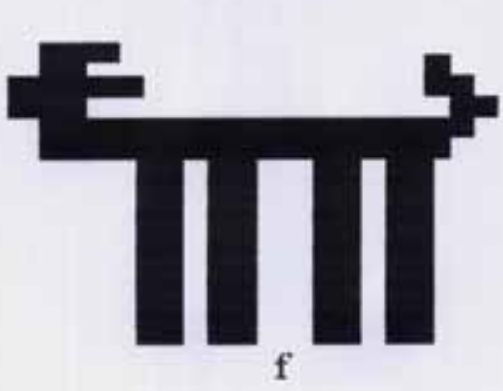
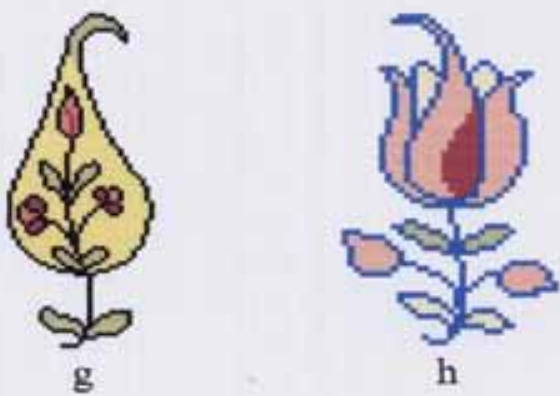

Şekil 6. Cecimlerde Kullanılan Motif Örnekleri.

kaydediyor. Bu tür ipek iplikler eğirilmiş olduğu için yapısı sağlam olmakta ve ipeğe ait esas özelliklerini korumaktadır. İpliklerin makinede değil, elle eğirilmiş olduğu, ipek ipliklerin hiçbirinin terkibinde serisin (yapıştırıcı madde) olmadı ̆̆ı, çözgü ipliklerinin tamamının sağ $Z$ yönlü eğirme bükümlü olup iki kat bükümlü iplik hazırlanırken sol S yönlü büküm kullanıldığı (Z2S), atkı olarak bir üründe aynı tipte (Z2S) ipek iplikle pamuk ipliğin beraber kullanıldığı, ikinci üründe sadece ipek iplik, üçüncü üründe ise atkı olarak iki adet üç kat bükümlü (Z3S) pamuk iplik kullanıldığı araştırmacı tarafından tespit edilmiştir (Merritt 1992: 82). Aynı ürünlerin iplik sıklığı da incelenmiş ve hem çözgüsü, hem de atkıSı ipek olan üründe $1 \mathrm{~cm}$.de 44-50 çözgü, 9-10 atkı ipliği, atkısı ipek-pamuk olan üründe 30-36 çözgü, 8-9 atkı, atkısı pamuk olan üründe ise 32-34 çözgü, 8-9 atkı ipliği olduğu görülmüştür (Wertime 1992: 76). Bu rakamlar, ipekli cecimlerin ne kadar ince ve zarif olduğunu, dolayısı ile kullanılan ipliklerin de yeterince ince, kaliteli iplikler olduğunu anlamaya yardımcı olabilir. Araştırmacıların vardığı önemli sonuçlardan biri XIX. yüzyılın birinci yarısından 1920 yılına kadar bir zaman kesitinde cecimlerde kullanılmış ipliklerin kalitesinde pek bir değişim görülmediğidir. Bu, cecim dokumacılığının oturmuş bir teknoloji süreç olduğunun, cecimlerin teknik özelliklerinin uzun zaman değişmediğinin göstergesi sayılabilir.

İpliklerde kullanılan boyaların tahlili XIX. yüzyıla ait cecimlerde yalnız doğal boyar maddeler kullanılmış olduğunu ve boya kalitesinin en yüksek düzeyde olduğunu, XX. yüzyılın başlarına ait üründe ise yalnız sentetik boyalar kullanılmış olduğunu ortaya çıkarmıştır (Wertime 1992: 76). Kırmızı renk elde etmek için koşenil (kırmız böceği), siyah ve sarı için nar kabuğu (değişik miktarda) veya sumak kullanılmış, yeşil renk ise sarı boyanmış ipliğin indigo ile boyan-

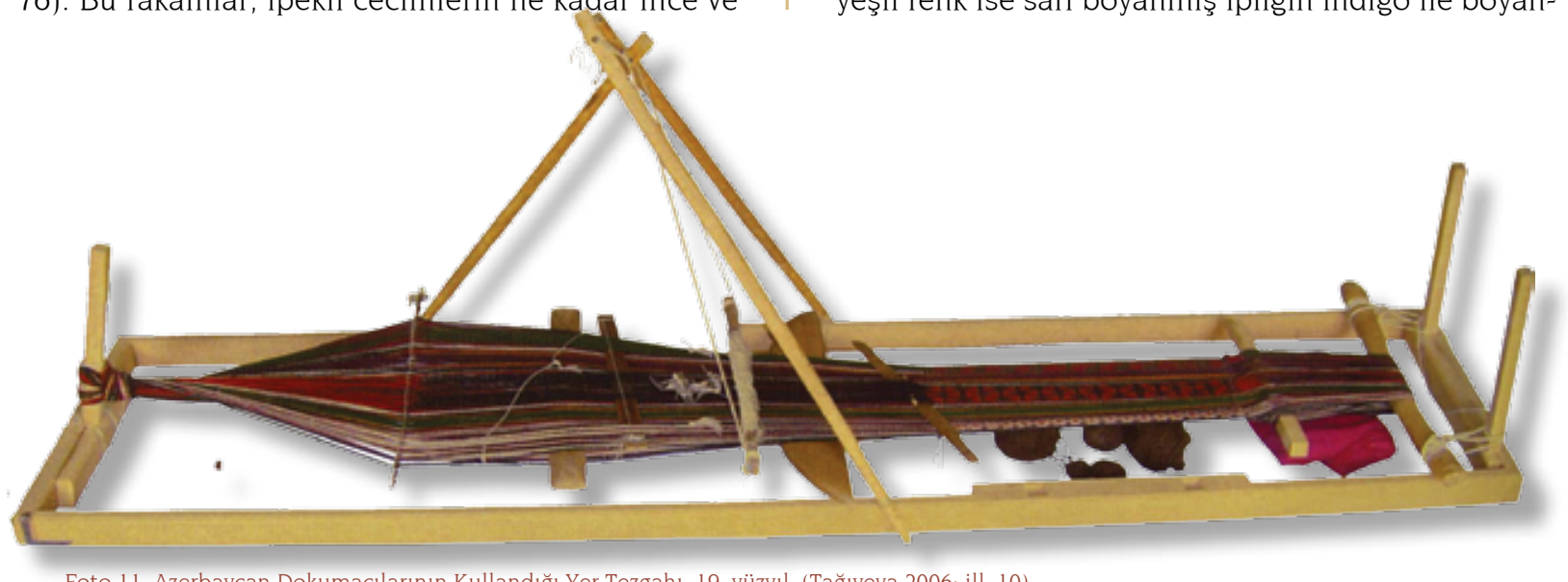

Foto 11. Azerbaycan Dokumacılarının Kullandığı Yer Tezgahı. 19. yüzyıl. (Tağıyeva 2006: ill, 10). 


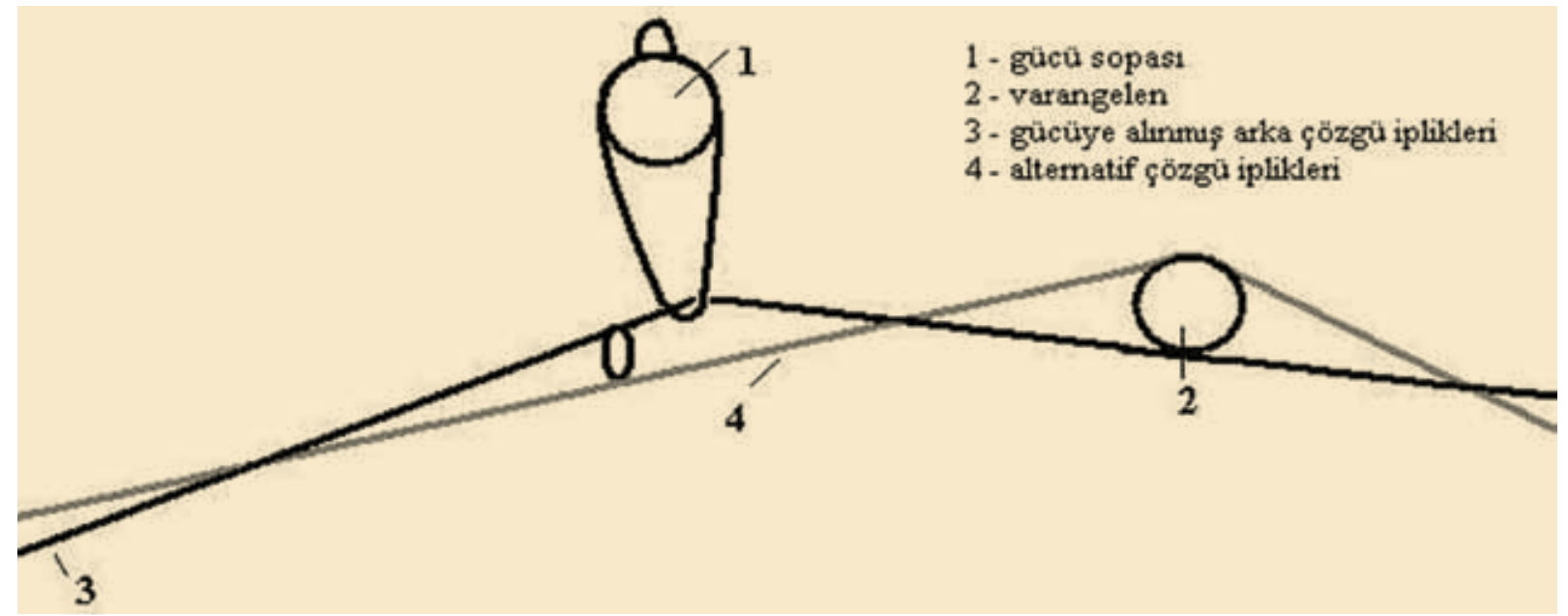

Şekil 7. Varangelenin Gücü Sopasından En Uzak Durumunda Açılan Ağızlık.

ması sonucu elde edilmiştir. XX. yüzyılın başlarına ait kaynaklarda tüm Azerbaycan dokuma sanatında boyama ile ilgili sorun yaşandı̆̆ı, doğal boyaların giderek kullanılmadığı, onların yerini ise kötü sonuçlar veren sentetik boyaların aldığı kaydedilmiştir (Piralov 1900: 19). Bununla beraber, A. S. Piralov (1925: 28) 1925 yılında hâlâ daha Aras nehri boyunca Önemli miktarda koşenil toplandığını yazmıştır. Bu ise sentetik boyalarla paralel doğal boyaların da kullanıldığı anlamına geliyor.

Cecimi şeritli kompozisyonundan dolayı genelde enine şeritli palasla karşılaştırıyorlar. Fakat bunların arasında çok önemli bir fark vardır: palas atkı yüzlü, cecim ise çözgü yüzlü dokumadır. Yani palasın şeritlerini renkli atkı iplikleri, ceciminkini ise renkli çözgü iplikleri oluşturmaktadır. Günümüze cecim dokumacılığında kullanılan iki tezgâh tipi ulaşmıştır (dikey ve yatay). XIX. yüzyılın sonuna doğru dikey tezgâh giderek kullanımdan kalksa da, Şirvan'ın bazı köylerinde hâlâ daha tatbik edilmekteydi (Şavrov 1902: 10). Fakat çoğunlukla basit yatay yer tezgâhları kullanılırdı (Foto 11.). Yer tezgâhı bin yıllardan beri var olan, günümüze adeta değişmeden ulaşmış ender aletlerden biridir ve hâlen dünyanın birçok yerinde kullanılmaktadır. Farklı kültürlerde kullanılan tezgâhların hepsi aynı prensiple çalışsa da, bazı farklılıkları vardır. Azerbaycan cecim dokumacılığında kullanılan yer tezgâhı Doğu Anadolu ve Toroslar Bölgesi'nde tevni veya üçayak, Karadeniz Bölgesi'nde dasdar adıyla bilinen (Deniz 2000: 69) tezgâhla benzerdir.

Azerbaycan dokumacılarının kullandıkları tezgâhta tek gücü sopası, çözgü ipliklerini iki kısma ayırmaktadır. Alternatif çözgü iplikleri gücüye alındıktan sonra gücü sopası en yüksek durumuna getirilerek bu durumda sabitlenir. Bunun için tezgâhın üstünde yerleştirilen ağaçtan hazırlanmış üçayak kullanılmaktadır. Gücü sopası bu pozisyonunda ağızlığı hep açık tutmaktadır (Şekil 7.). Ağızlığı değiştirmek için alternatif çözgü ipliklerinin yukarı kaldırılması gerekir. Bu işlem, gücü sopasının arka tarafında yerleştirilmiş gücüüstü ağacın (varangelenin) gücü sopasına doğru kaydırılması ile gerçekleştirilir (Şekil 8.). Dokumacı, atkı ipliklerini dokumaya vurmak için kullandığı özel yassı levhayı (kılıcı) döndürerek oluşmuş ağızlığı genişletir, yeni atkıyı buraya yerleştirir ve kılıcı önceki durumuna getirerek atkıyı dokumaya vurur. Sonra varangelen önceki durumuna getirilerek işlem devam ettirilir. Doku-

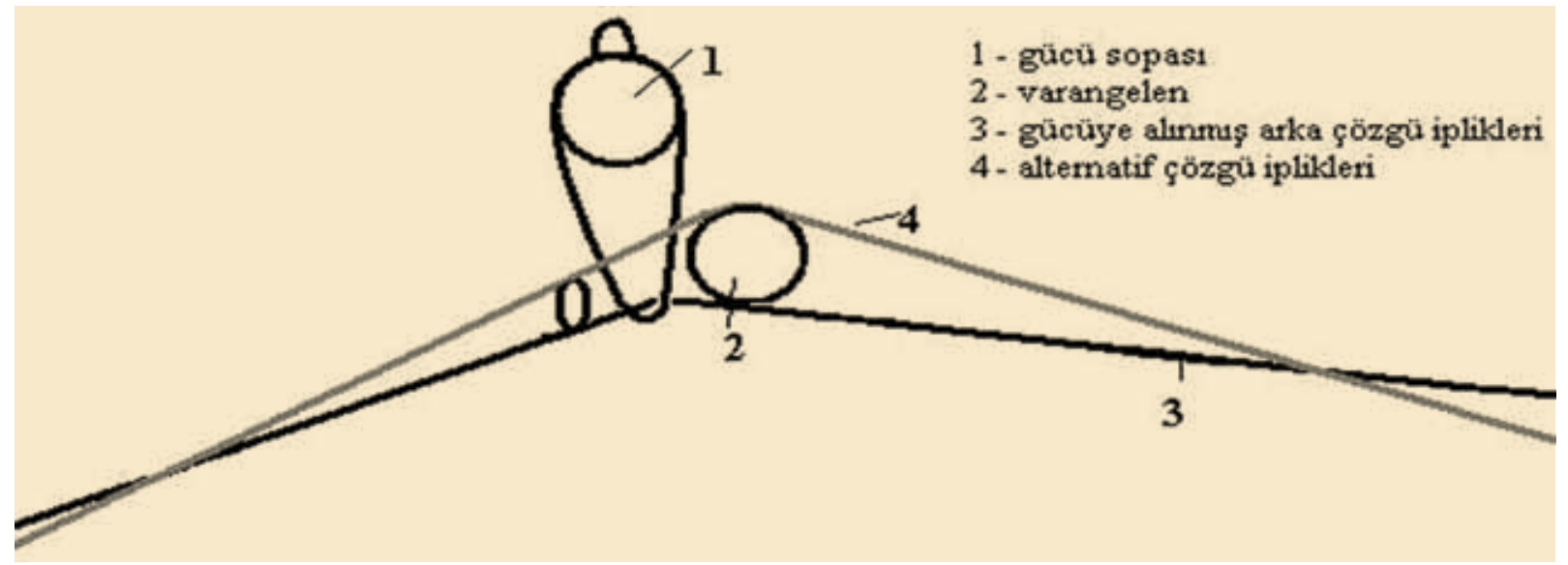


ma ilerledikçe gücü sopası ve onu sabitleyen üçayak da tezgâh boyunca ileri taşınır.

Dokumacının kullandığı kılıç yer tezgâhında önemli parçalardan biridir ve hem ebadına, hem de formuna göre farklılık gösterebilir. Azerbaycan dokumacıları yay formuna sahip levha kullanmışlardır. Tüm çözgü ipliklerini kapsayabilmesi için bu levhanın uzunluğu çözgünün genel eninden büyük olmalıdır. Atkı ipliğinin çözgülerin arasında saklanmasını sağlamak için onu yeterince büyük kuvvetle vurmak gerekir. Bu nedenle yassı levha genelde çok sağlam ağaçtan yapılır.

A. Mustafayev'in yazdığına göre (1991: 52), XIX. yüzyılın ikinci yarısında Azerbaycan cecim dokumacılığında kullanılan yer tezgâhının yapısı biraz değiştirilmiş, gücü sopası ve kılıç yerine nire ve şanalı deftin (gücü çerçeveleri ve tarak) kullanılmaya başlamıştır. Ayrıca, sabit dolağacların (çözgü ve kumaş leventlerinin) yerini döndürülebilen neverdler (çözgü ve kumaş leventleri) almıştır. Fakat cecim dokumacılığının yayıldığı birçok bölgede eski yapılı tezgâh kullanılmaya devam etmiştir.

Cecim dokumak için tezgâhta yaklaşık 15-16 m uzunluğunda çözgü hazırlanır. Çözgü hazırlarken dokumacl, dokuyacağı cecimin kompozisyonunu göz önünde bulundurarak çözgüyü şeritlerin rengine ve genişliğine uygun olarak hazırlar. Yani tezgâha sarılan çözgü, çeşitli renkte ve genişlikte iplik gruplarının sıralanmasından oluşur. Her gruptaki iplik sayısı onların oluşturduğu şeridin genişliğine bağlıdır. Dokumanın tam eni ise 30-35 cm.den büyük olmamaktadır. Çünkü dokuma sırasında cecim, dokumacının bacakları arasında yer alır.

Çözgü yüzlü dokumada çözgü ipliklerinin sıklığı atkı ipliklerine göre daha yüksek olmalı ve atkı iplikleri çözgülerin arasında saklanmalıdır (Mallett 2000: 27) (Foto 12.). Yukarıda verilmiş cecimde ipliklerin sıklığgnı ifade eden rakamlardan da bu görülmektedir. Cecimin dokunma özelliğine bağlı olarak onun hemyan ve alaköynek çeşitleri ayırt edilir (Aliyeva 1990: 40). Hemyan cecim ince, sık ve sağlam dokusu, her iki yüzeyinin de pürüzsüz oluşu ile seçilen sade şeritli çözgü yüzlü düz dokumadır. Bu dokumada çözgü ve atkı ipliklerinin kalınlığı birbirine yakındır, dokunması için daha fazla zaman ve malzeme gerekir. Bu cecim çeşidine bazı yerlerde vazı veya saya cecim de deniyor. Yüksek kaliteli ipekle dokunmuş hemyan cecim özellikle kadın giysilerinde daha çok kullanılmıştır. Alaköynek cecim, hemyana göre daha kalın ve yüzeyi rölyeflidir. Atkı iplikleri çözgüden kalın olduğu halde dokumanın üzerinde yatay yönde kabarık çizgiler oluşur ve dokumanın yüzeyi rölyefli görünüm kazanır. Bu dokuma daha az zaman ve malzeme gerektirir, hemyana göre daha aşağı kaliteye sahiptir. Düz şeritli olduğu gibi, desenli de olabilir. Düz şeritli alaköynek cecimin ağ ebirli, alaca, al yerli, tırnaklı, haskırmızı, miyani, tetinlik, şanadişi, desenli alaköynek cecimin çiçekli, ladı-cecim isimleri ile bilinen çeşitleri vardır (Tağıyeva 2006: 70). Alaköynek cecim

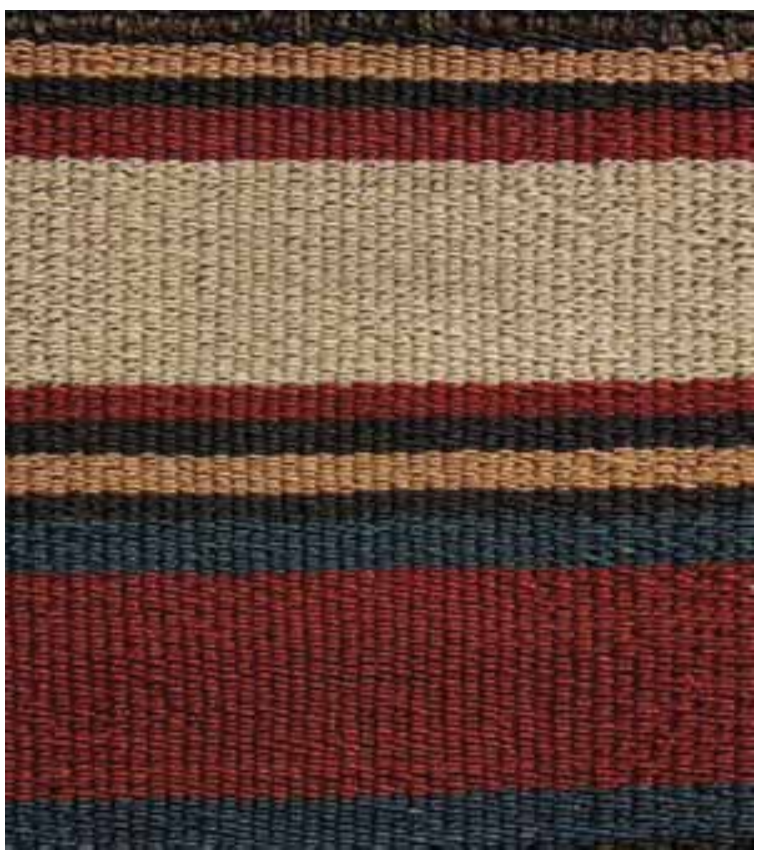

Foto 12. Çözgü Yüzlü Dokuma. Yünlü Cecim. 241 x 274 cm. 19. yy. Güney Azerbaycan. Tribalchase Galerisi, İstanbul.

ipekli ve yünlü olabilir. Eskiden döşek yüzü, yük örtüsü, taht örtüsü, hurcun, eğer örtüsü vs. kısmında kullanılırdı. XIX. yüzyılın sonu ve XX. yüzyılın başlarında bazı araştırmacılar Azerbaycan cecimlerini dokunma ve kompozisyon özelliklerine, kullanılan malzemeye, kullanım alanına vs. göre sınıflandırmaya çalışmışlar (Abelov 1887: 174-175, SMOMPK 1891:126-127, Mirimanov 1896: 94). Onların sinıflandırmalarında da hemyan, alaköynek, obagezer, saya, döşeküzü, gül yaprağı, tırnakl, çargat, ă̆ yerli, ağ ebirli, yorğanüzü gibi cecim çeşitlerinin adları verilmiştir.

Düz renkli şeritlerden oluşan cecimlerin dokunma işlemi sadedir. Dokumacı her yeni dokuma elementini oluşturmak için atkı ipliğini ağızlığa yerleştirir ve iyice bastırarak dokuma başlangıcına sıkıştırır. Dokuma işlemi bu şekilde devam eder.

Desenli cecimlerin dokunması biraz daha karmaşıktır. Azerbaycan cecimlerinde desenli şeritlerin dokunması için genelde iki farklı renkte çözgü ipliğinin karşılıklı yer değiştirmesi işlemi tatbik edilmiştir. Motifin dokunmasında iştirak eden çözgü ipliği dokumanın yüz tarafında yer aldığı zaman diğer renkteki çözgü ipliği arkaya geçer ve atkılarla hiçbir bağlantı oluşturmadan serbest kalır (Foto 13.). Motifte diğer renk ipliğin sırası geldiğinde bu çözgülerin yerleri değiştirilerek bu defa diğer çözgü ipliği arkaya geçer ve işlem bu gaydada devam eder. Bu dokuma için çözgü hazırlanırken desenli şeritlerin olduğu kısımlarda çözgü ipliklerinin sayısı 2 kat fazla götürülür (tek çözgü iplikleri yerine açık ve koyu çözgü çiftleri şeklinde), çünkü çözgülerin yarısı dokumadan kenarda kalmaktadır. Bu nedenle de desenli şeritte çözgü ipliklerini sayarken sadece yüz tarafta olan iplikler sayılmalıdır. 


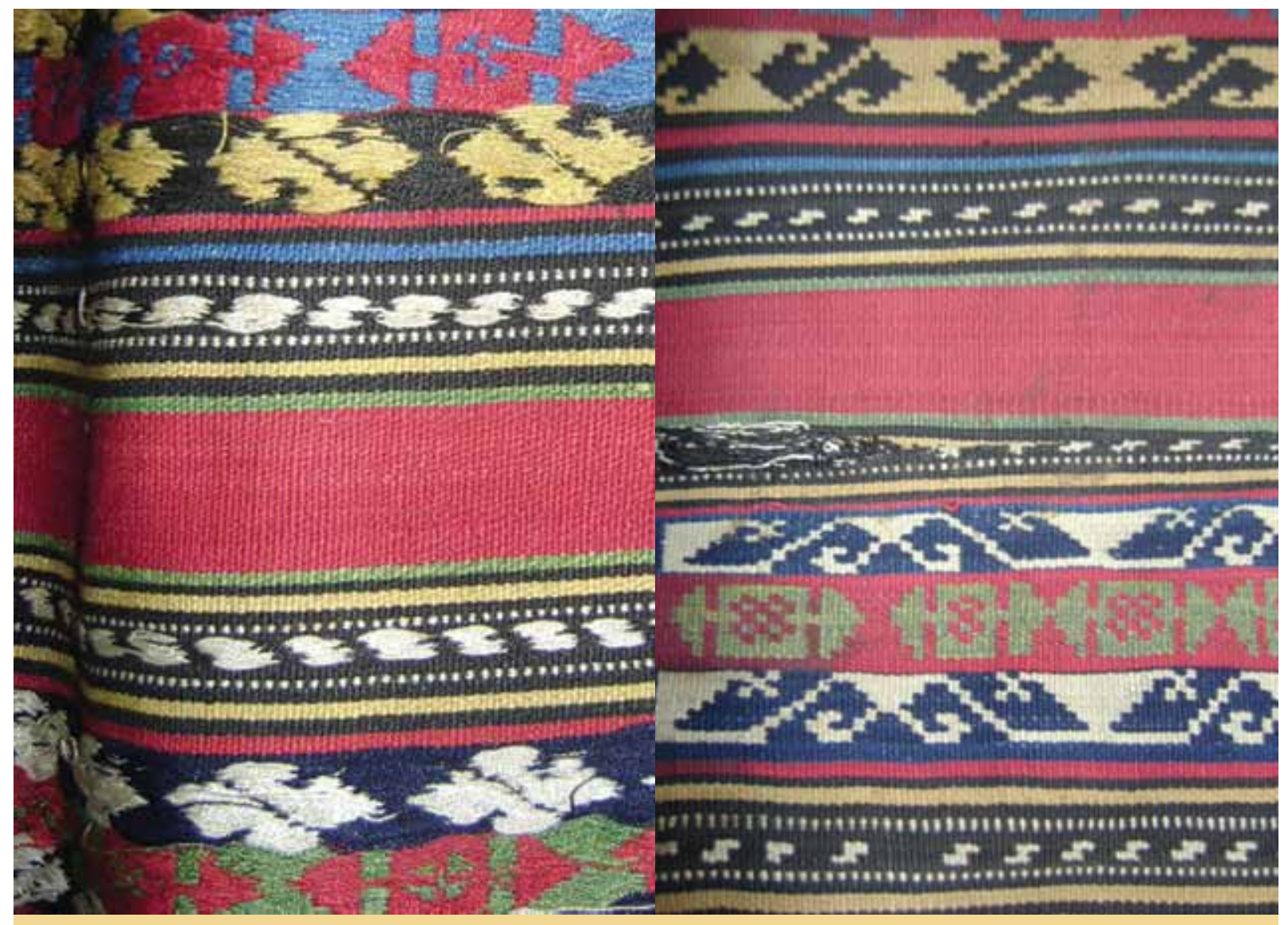

Foto 13. Çözgü Yüzlü Ipekli Cecim Dokumanın Ön Ve Arka Yüzleri. 170 x 370 cm. 1870. Lemberan. Azerbaycan Tarihi Müzesi, Bakü, inv. no. 2266.

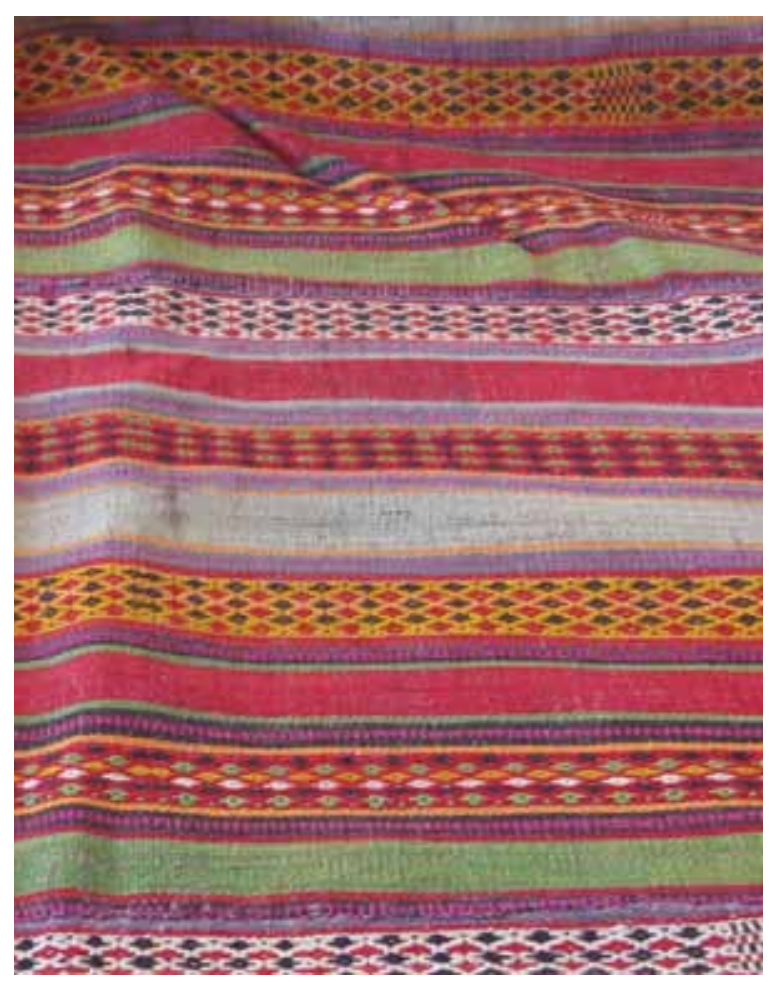

Foto 14. İpekli Ladı-Cecim Örneği. 142 x 176 cm. Azerbaycan Tarihi Müzesi, Bakü, inv. no. 8486 .

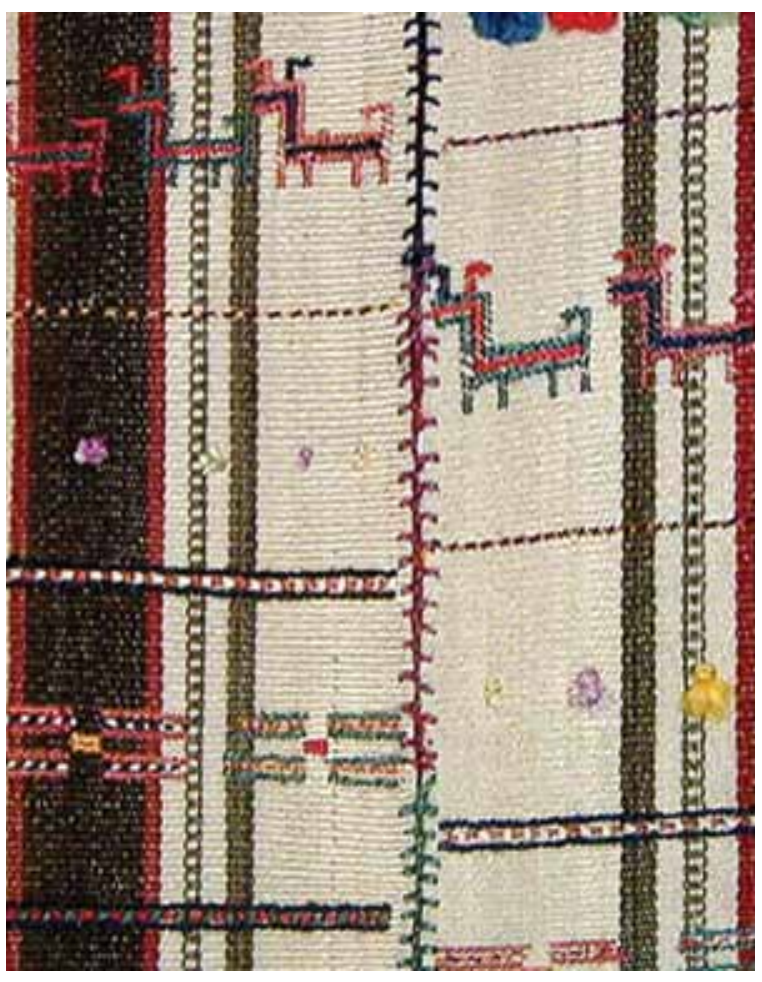

Foto 15. Sumak Tekniği İle Desenlenmiș Cecim. 179 x 278 cm. Doğu Azerbaycan. 20. yy. başl. Alberto Boralevi Galerisi, Milan. 
Dokuma sırasında dokumacı desenli kısmın tüm çözgülerini desene uygun şekilde seçtikten sonra yeni oluşturduğu ağızlığa atkı ipliğini yerleştirir. Atkıyı sıkıştırdıktan sonra bir sonraki sıranın çözgülerini seçerek işlemi tekrar eder. Genelde desenli şeridin genişliği, dokumacının çözgüleri seçerken bir eline toplayabildiği çözgü ipliklerinin sayısı ile sınırlandırılmaktadır. Bu yüzden de bu şeritler pek geniş değildir.

Kaydetmek gerekir ki, sözünü ettiğimiz dokuma işlemi çok zaman gerektiren, yorucu ve sıkıcı bir işlemdir. Günümüzde tekstil ürünlerini gelişmiş teknolojilerle elde eden insanlar geleneksel yöntemleri kullanmaktan vazgeçtiği için dokuma gelenekleri, maalesef, kayboluyor.

Bazı desenli cecimlerde desenler farklı yöntemlerle oluşturulmuştur. Örneğin, ladı-cecim ismi ile bilinen cecimlerin desenli kısımlarında zemin çözgülerinden başka değişik renklerde desen çözgüleri bulunur. Motifler, bu çözgü ipliklerinin dokuma sırasında birkaç atkının üstünden atlaması ile ortaya çıkan kısa dikey çizgilerle oluşturulur (Foto 14.). Bu nedenle desen bir dereceye kadar kabarık görünüme sahip olmaktadır. $\mathrm{Bu}$ yöntemle desenleme için 2-3 farklı renkte çözgü ipliği kullanılabilir. Bir başka cecim çeşidinde desen, ek desen atkılarının kayık tekniği (sumak tekniği) ile çözgülere dolanması ile oluşturulur (Foto 15.). Fakat bu desenleme teknikleri çok da yaygın değildir. Bunlardan başka cecimlerin desenlendirilmesi için işleme tekniği de kullanılmıştır (Foto 9.). Düz cecimin şeritleri üzerine bitkisel desenlerin işlenmesi yöntemi ile hazırlanan cecimlere çiçekli cecimler örnek olabilir.

\section{Azerbaycan Cecim Dokumacılığının Günümüzdeki Durumu}

Yüzyıllar önceki göçebe toplulukların yaşamının çok değiştiği, onların çoğunlukla yerleşik hayat tarzına geçtiği bellidir. Dolayısı ile eskiden çöl yaşamında alaçık olarak adlandırılan çadır evinin her köşesinde çeşitli amaçlarla dokuma ürünler kullanan, hatta üstüne giydiği elbisenin kumaşını bile kendisi yapan insanların hayatı kökünden değişmiştir. Bu nedenle onların eskiden yaptıkları birçok dokuma ürününe duyulan ihtiyaç ortadan kalkmıştır. Herkese belli olan şehirlerde merkezleşen yaşam, sanayileşme vs. bu gibi nedenleri bir daha saymaya gerek olmadığını düşünerek sadece şunu belirtmek gerekir ki, birçok dokumalarımız gibi cecimler de yok olma aşamasındadır. Şimdilik köylerde hâlen kullanımda olan eski örnekler bulunsa da (Nooter 2004: pl. 122-130), artık yeni cecimler yapılmamaktadır. Birçok köyde cecim dokuması yapabilen son kişiler artık bu işi yapamayacak yaştalar ve genç nesil de onlardan bu mesleği öğrenmek isteğinde değildir. Diğer taraftan, Azerbaycan'ın cecim dokumacılık merkezlerinden biri olan Garabağ işgal altındadır. Bu bölgenin kaçkın durumunda olan halkı geleneksel yaşamını tamamen kaybetmiştir. Bu gün toplu şekilde Garabağ halkından ve onun ne ile meşgul olduğundan söz etmek mümkün değildir.
Böylece kültürümüzün bir köklü katmanı da kaybolma arifesindedir. Devlet ve bizi biz yapan kültürümüzün yaşatılması ile ilgili kamu kurumları en kısa zamanda kaybolmaya yüz tutmuş eski sanatlarımızın yaşatılması için önemli tedbirler almazsa, Azerbaycan'da dokumacılık sanatının bir dalını da kaybetmiş olacağız.

\section{Kaynaklar}

Abdullaeva, N. (1971), Kovrovoe iskusstvo Azerbaydjana, Baku: Elm.

Abelov, N. A. (1887), İssledovaniya ekonomiçeskogo bita gosudarstvennih krestyan Geokçayskogo i Şemakhinskogo uyezdov Bakinskoy gubernii. Material dlya izuçeniya ekonomiçeskogo bita gosudarstvennih krestyan Zakavkazckogo kraya, Cilt VI, II. hisse, Tiflis.

Aliyeva, G. (1990), Azerbaycan Bedii Parça ve Tikmeleri, Bakı: Elm Aliyeva, K. (1988), Bezvorsoviye kovrı Azerbaydjana, Baku: İşıg.

Bagirzade, M. (1926), "Lenkoranskiy uezd”, Maarif işçisi, No: 5-6, Bakı.

Deniz, B. (2000), Türk Dünyasında Halı ve Düz Dokuma Yaygilar, Ankara: AKM Yayınları.

Gans-Ruedin, E. (1986), La Tapis du Caucase, Paris: Office du Livre.

Görgünay-Kırzıoğlu, N., (2001), Altaylar'dan Tunaboyu'na Türk Dünyası'nda Ortak Yanışlar (Motifler)/ Halılar, Benzeri Dokumalar, Giysiler, Mimarî Eserler ile Değişik Eşya ve Paralarda, Ankara: Türk Tarih Kurumu Basımevi.

Kerimov, L. (1961), Azerbaydjanskiy kovyor, Cilt 1, BakuLeningrad: İzdatelstvo Akademii Nauk Azerbaydjanskoy SSR.

Kerimov, L. (1983), Azerbaydjanskiy kovyor, Cilt III, Baku: Gyandjlik.

Lamb, V. (2005), Looms Past and Present. Around the Mediterranean and Elsewhere Hertfordshire: Roxford Books.

Mallett, M. (2000), Woven Structures, Atlanta: Christopher Publications.

Merritt, J. L. (1992), "Three Silk Jajims. Interpreting the Textiles", Hali, Is. 63, pp. 79-83, London: Hali Publications Ltd.

Mirimanov, G. A. (1896), Kustarnıye şelkovte promıslı Şuşinskogo uyezda. Trudı Kavkazskoy Şelkovodstvennoy Stantsii, Cilt VIII, Tiflis.

Nooter, R. H., Koshoridze, I., Tatikyan, V., (2004), Flat-woven Rugs \& Textiles from the Caucasus, Atglen: Schiffer Publishing Ltd.

Piralov, A. S. (1900), Kratkiy oçerk kustarnıkh promislov Kavkaza, Tiflis.

Piralov, A. S. (1913a), Kratkiy oçerk kustarnıkh promıslov Kavkaza. Kustarnaya promışlennost Rossii, Cilt II, St. Peterburg Lito-tipografiya "Yakor".

Piralov, A. S. (1913b), Razniye promıslı. Kustarnaya promışlennost Rossii, St. Peterburg: Lito-tipografiya "Yakor".

Piralov, A. S. (1925), "Kustarnaya promışlennost Zakavkazya", Vestnik promislovoy kooperatsii, 8-9, St. Peterburg: İzdanie Vserossiyskogo Soyuza Promislovoy Kooperatsii.

S6ornik materialov dlya opisaniya mestnostey i plemyon Kavkaza, (1891), Bur. XI, Tiflis: Tipografiya Glavnogo upravleniya Namestnika Kavkazskogo.

Şavrov, N. N. (1902), Kustarnı şelkovie promıslı Kavkaza. Trudı Kavkazskoy Şelkovodstvennoy Stantsii, Cilt XII, Bur. III, Tiflis.

Tağıyeva, R. (2006), Azerbaycan khalçası meişetde, Bakı: Tutu neşriyatı.

Vezirov, H. (1929), "Şura Azerbaycanında cecimin kustar senayesi", Igtisadi heberler, No: 10-11, Bakı.

Wertime, J. T. (1992), "Three Silk Jajims. The Tradition”, Hali, Is. 63, pp. 72-76, London: Hali Publications Ltd.

Wright, R. E. (1992), "Three Silk Jajims. The Silk Business", Hali, Is. 63, pp. 76-79, London: Hali Publications Ltd. 